\title{
Delineation of groundwater potential zones in the crystalline basement terrain of SW-Nigeria: an integrated GIS and remote sensing approach
}

\author{
Olutoyin A. Fashae $\cdot$ Moshood N. Tijani • \\ Abel O. Talabi · Oluwatola I. Adedeji
}

Received: 15 March 2013/Accepted: 2 September 2013/Published online: 5 October 2013

(C) The Author(s) 2013. This article is published with open access at Springerlink.com

\begin{abstract}
Due to complex and erratic nature of groundwater occurrences in crystalline basement terrains, groundwater development in form of boreholes/wells without the necessary pre-drilling hydrogeological investigations usually results in failure. Therefore, there is the need for adequate characterization of aquifers and delineation of groundwater potential zones in such crystalline basement setting. This study employed the integration of multi-criteria decision analysis (MCDA), remote sensing (RS) and geographical information system (GIS) techniques to delineate groundwater potential zones in crystalline basement terrain of SW-Nigeria and validation of the result with existing borehole/well yield data. The study approach involved integration of nine different thematic layers (geology, rainfall geomorphology, soil, drainage density, lineament density, landuse, slope and drainage proximity) based on weights assignment and normalization with respect to the relative contribution of the different themes to groundwater occurrence using Saaty's analytic hierarchy approach. Following weigh normalization and ranking, the thematic maps were integrated using ArcGIS 10.0 software to generate the overall groundwater potential map for the study area. The result revealed that the study area can be categorized into three different groundwater
\end{abstract}

O. A. Fashae $(\varangle) \cdot$ M. N. Tijani

Department of Geography, University of Ibadan, Ibadan, Nigeria e-mail: toyinafashae@yahoo.com

\section{A. O. Talabi}

Department of Geology, University of Ado-Ekiti, Ado Ekiti, Nigeria

O. I. Adedeji

Institute of Ecology and Environment Studies, Obafemi Awolowo University, Ile-Ife, Nigeria potential zones: high, medium and low. Greater portion of the study area $\left(84,121.8 \mathrm{~km}^{2}\right)$ representing about $78 \%$ of the total area, fall within the medium groundwater potential zone which are generally underlain by medium-porphyritic granite, biotite-hornblende granite and granite gneiss bedrock settings. About 18,239.7 km² (17\%) fall under high groundwater potential zone which are characterized by weathered/fractured quartzite, quartz-schist, amphibolite schist and phyllite bedrock settings. However, areas of low groundwater potentials constitute only $3 \%\left(3,416.54 \mathrm{~km}^{2}\right)$ of the total study area and are mostly underlain by migmatite, banded and augen gneiss bedrock settings. Subsequent validation with boreholes/well yield data revealed a good correlation with respect to the observed groundwater potential zonation. Wells/boreholes with yields greater than $>150 \mathrm{~m}^{3} /$ day are generally characteristic of areas with high groundwater potential while those with yields of 75-150 and $<75 \mathrm{~m}^{3} /$ day are typical of areas with medium and low groundwater potentials, respectively. The validation clearly highlights the efficacy of the integrated MCDA, RS and GIS methods employed in this study as useful modern approach for proper groundwater resources evaluation; providing quick prospective guides for groundwater exploration and exploitation in such crystalline basement settings.

Keywords Groundwater potential zones - Crystalline basement terrains - Geographical information systems . Remote sensing $\cdot$ Multi-criteria decision analysis

\section{Introduction}

The ever increasing population in the developing world, especially in the sub-Sahara Africa, coupled with 
increasing agricultural and industrial development warrants greater demand for essential public utilities, most especially water supply for domestic and agricultural purposes. However, the reality of poor economic situation and challenges of expansion of many basic infrastructural facilities to meet the increasing demand on the parts of the government warrants the need for individuals and local communities to look for alternative to the conventional public water supply (Aggarwal et al. 2009; Rodell et al. 2009; Chawla et al. 2010).

Consequently, the readily available alternative option to the epileptic pipe-borne water supply from reservoirs and dams is the development of groundwater system in the form of dug wells and boreholes, especially in the crystalline basement terrains, where shallow groundwater systems can be tapped with minimal cost compared to with the costlier surface water development. Groundwater is said to be a more dynamic renewable natural resource and plays important role in drinking, agricultural and industrial needs as a timely assured source compared with surface water; however, availability with good quality and quantity in appropriate time and space is also important (Rao 2006; Chowdhury et al. 2009).

Nonetheless, a major constraint is the complex and erratic nature of groundwater occurrences in crystalline basement terrains with attendant high rate of well/borehole failure in the absence of proper and adequate pre-drilling hydrogeological investigations. The occurrence and movement of groundwater in a crystalline terrain depends on the degree of weathering and extent of fracturing of the bedrock rocks, while identification of potential groundwater zones could aid in proper development and utilization of groundwater resources for eliminating water scarcity (Rao 2006). However, indiscriminate exploitation can lead to decrease in groundwater potential in terms of lowering of water level (hence increase in cost of groundwater withdrawal) and sometimes deterioration in groundwater quality. Therefore, there is the need for adequate characterization of basement aquifers and delineation of groundwater potential zones.

Till now, several conventional methods such as geological, hydrogeological, geophysical and photogeological techniques were employed to delineate groundwater potential zones (McNeill 1991; Lillesand and Kiefer 1994; Teeuw 1995; Meijerink 1996; Edet and Okereke 1997; Sander et al. 1996; Taylor and Howard 2000; Shahid et al. 2000; Srivastava and Bhattacharya 2006). However, in the recent years, with the advent of powerful and high-speed computers, digital technique is used to integrate various conventional methods with satellite image/remote sensing (RS) techniques and geographical information systems (GIS) technology (Chenini et al. 2010; Machiwal et al. 2011; Talabi and Tijani 2011). Geographical information system (GIS) provides an excellent framework for efficiently handling large and complex spatial data for natural resources management (Jenson and Trautwein 1987; Burrough 1986). This integrated approach helps to increase the accuracy of results in delineation of groundwater potential zone and also to reduce the bias on any single theme (Rao and Jugran 2003). Therefore, a systematic approach to groundwater exploration using modern techniques is essential for the proper evaluation, exploitation and management to ensure sustainable development of this seemingly valuable resource, especially in the crystalline bedrock terrain.

Consequently, integration of remote sensing (RS) and geographic information system (GIS) has proven to be efficient, rapid and cost effective technique producing valuable data on geology, geomorphology, lineaments and slope as well as a systematic integration of these data for exploration and delineation of groundwater potentials zones (Prasad et al. 2008). Furthermore, such integrated RS-GIS approach enables manipulation of large data base for large areal extent covering, even in inaccessible areas (Singh et al. 2013), thus providing a synoptic view of large areas (with associated hydrological information) for rapid and cost effective assessment of groundwater occurrences.

In the recent years, there have been wide applications of RS and GIS in hydrogeological researches. A number of workers such as Edet et al. (1997), Murthy (2000), Obi Reddy et al. (2000), Pratap et al. (2000), Singh and Prakash 2002 and Jaiswal et al. (2003) have used GIS to delineate groundwater potential zone, while Sreedevi et al. (2001) also applied remote sensing techniques in the delineation of groundwater potential zones. Furthermore, many authors such as Krishnamurthy et al. (1996), Murthy (2000), Srivastava and Bhattacharya (2006), Shahid et al. (2000) and Khan and Maharana (2002) have applied both remote sensing techniques and GIS applications in groundwater exploration, delineation of groundwater potential zones as well as identification of artificial recharge sites. In addition, El-kadi et al. (1994), Novaline et al. (1999), Shahid et al. (2000), Boutt et al. (2001), Saraf et al. (2004) Rokade et al. (2007) and Gumma and Pavelic (2013) have carried out groundwater modelling through the use of GIS. In addition, GIS has also been considered for multi-criteria analysis in resource evaluation, for example Saraf et al. (2004) and Rao and Jugran 2003 have used GIS technology for processing and interpretation of groundwater quality data.

In the crystalline basement terrain of SW-Nigeria which constitutes almost one-fifth of Nigeria, groundwater occurrences are largely limited to shallow weathered overburden units and degree of fracturing of the bedrocks. These serve as the main sources of freshwater supply for domestic and industrial purposes, especially in the rural and sub-urban areas with no public/municipal water 


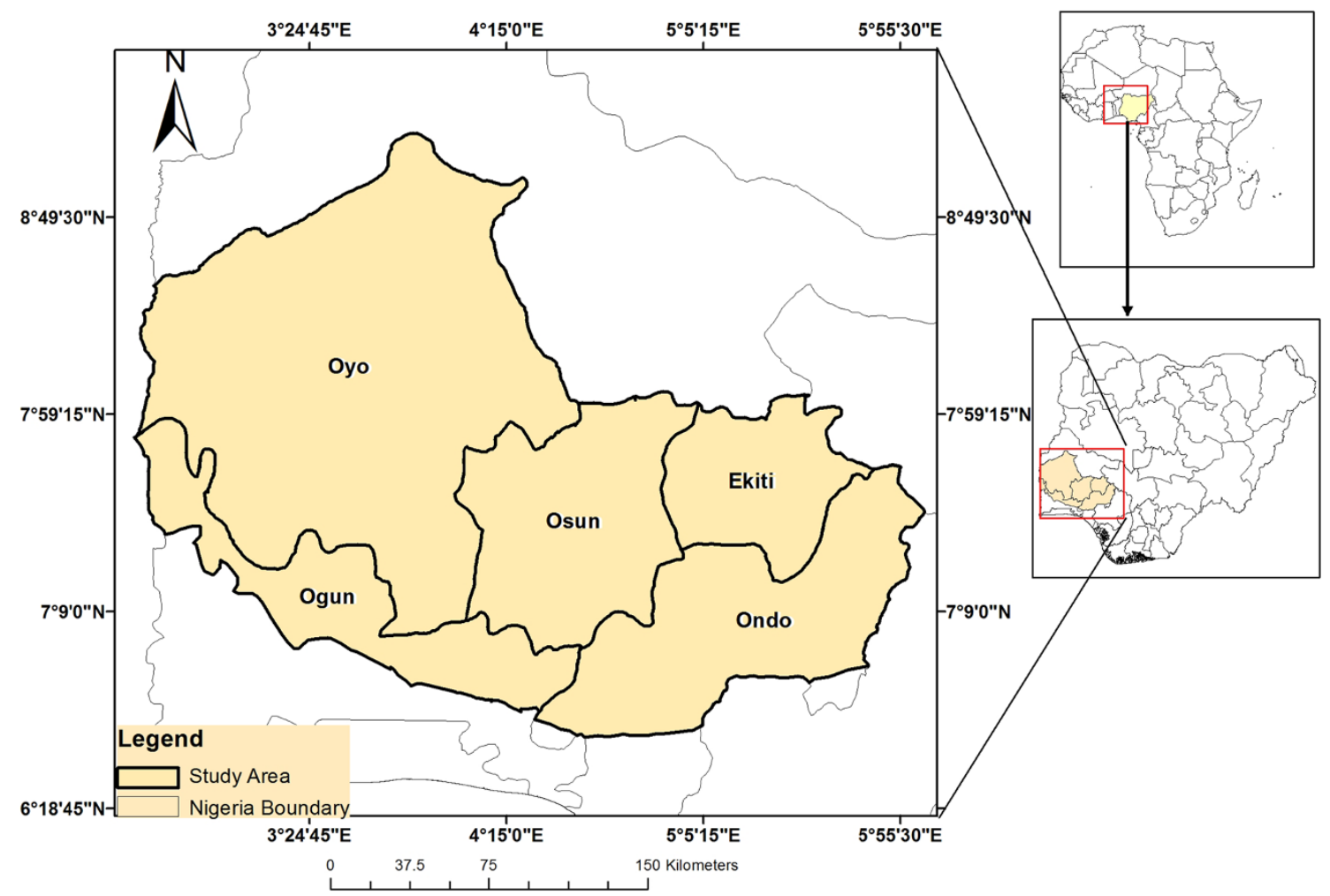

Fig. 1 Map of Nigeria showing the study area

supply. In addition, it should be noted that since early 1990s, most of the major cities and urban centres are increasingly relying on groundwater system too, due to the failing public/municipal pipe borne-water supply systems. This situation had resulted in a significant increase of indiscriminate exploitation of groundwater resources and random sitting of dug-wells and boreholes leading to attendant high failure rate. Consequently, to forestall possible negative impacts of indiscriminate exploitation in terms of lowering of water level and groundwater quality deterioration, it is, therefore, necessary to have a proper understanding of the hydrogeological condition and groundwater potentiality in such basement terrain.

However, few studies have been conducted in demarcating potential groundwater resources within the basement complex region of Nigeria (Edet et al. 1997), the limitations of which include usage of only two variables (drainage densities and lineament densities) and covered a very limited area. Therefore, the present study attempted to cover larger areas in the SW-Nigeria using more variables with the inclusion of the multi-criteria decision analysis (MCDA) technique. This gives a broader view of the potential groundwater distribution in the study area. Furthermore, the Analytic Hierarchy Process (AHP) (Saaty 1980, 1986, 1992), an international acceptable quantitative tool, adopted in this study appears to be a flexible decision making tool for multiple-criterion problems such as the assessment of the potential zones of groundwater resources in rapidly urbanized area of SW-Nigeria. It enables decomposition of a problem into hierarchy and assures that both qualitative and quantitative aspects of a problem are incorporated in evaluation process. AHP has been successfully applied in several studies of water resources management by integrating MCDA (Saaty 1980, 1986, 1992) with RS and GIS techniques (Srivastava and Bhattacharya 2006; Jha et al. 2010; Machiwal et al. 2011; Mukherjee et al. 2012; Singh et al. 2013).

Therefore, the present study employed AHP-coupled MCDA, GIS and RS techniques to integrate hydrogeological, geomorphologic as well as climatic data in respect of groundwater resources evaluation of the Basement Complex terrain of SW-Nigeria. The intent is to delineate the groundwater potential zones of the study area and to develop a prospective guide map for groundwater exploration/exploitation so as to ensure optimum and sustainable management of this vital resource.

\section{The study area}

The study area, the Basement Complex terrain of southwestern part of Nigeria, lies between longitude $2^{\circ} 42^{\prime} \mathrm{E}$ to 
$6^{\circ} 2^{\prime} \mathrm{E}$ and latitude $6^{\circ} 5^{\prime} \mathrm{N}$ to $9^{\circ} 11^{\prime} \mathrm{N}$ encompassing Oyo, Ogun, Osun Ekiti and Ondo State regions of Nigeria (Fig. 1).

It covers approximately $137,268 \mathrm{~km}^{2}$ representing about one-fifth of the total land area of Nigeria. The terrain is characterized by Precambrian crystalline rock units and bordered to the south by the western Dahomey Basin. The area is bounded in the north by massive granitic hills where most of the drainage originates. The entire area is drained by medium- to small-sized rivers and streams, which flow southwards to the Atlantic Ocean.

The topography of Nigeria and indeed the study area is a reflection of its geology, as the Basement Complex rocks of the SW-Nigeria are responsible for the rugged topography that dominates substantial portion of the study area. In general, the elevation ranges from $600 \mathrm{~m}$ asl in the north and north eastern parts to less than $300 \mathrm{~m}$ asl in the southern part, while the Idanre Hills represent the highest plateau with an elevation of about $1,000 \mathrm{~m}$ above sea level (Iloeje 1981). The topography of the area exhibits three distinct features: hilly terrains covering mainly northern and north-western part of the basin, mid-slope region with moderate undulating terrain and relatively flat region with gentle slope covering larger part of the basin.

The study area enjoys a warm tropical climate with relatively high temperatures throughout the year and two seasons. Generally, temperatures are high throughout the year because of the tropical climatic conditions with mean monthly value of about $27^{\circ} \mathrm{C}$, while daily maximum temperatures range between 25 and $30^{\circ} \mathrm{C}$ depending on the location and season (Iloeje 1981). The seasonal pattern is characterized by long wet season between mid-March and July which is characterized by heavy rainfall and high humidity followed by a short dry season between July and August and a short wet season (September-October) before the commencement of the dry season in November (Oyenuga 1967; Iloeje 1981). The total annual rainfall decreases from the south to the northern parts of the study area with annual rainfall in the range of 1,000-1,400 $\mathrm{mm}$. However, about $80 \%$ of the rains fall within the wet months of April-September (Iloeje 1981). Soil types are influenced by and follow very broadly the climatic and vegetational zones of the study area, as the degree of available moisture in the soil is an important factor in soil reactions, fertility and productivity (Oyenuga 1967). The soils range from that of humid tropical forests zone in the south to that of derived savannah in the north of the study.

Geological and hydrogeological settings of the study area

The Basement Complex terrains of South-western Nigeria are underlain by Precambrian basement rocks, which comprise of crystalline igneous and metamorphic rocks mostly granite/porphyritic granite, granite-gneiss, quartzschist, migmatite as well as augen-gniess, pegmatite intrusions and variably migmatized biotite-hornblende gneiss. Descriptions on the field and petrographic/mineralogical characteristics of the different rock types are subject of various works such as Oyawoye (1972), Elueze (1982), Obaje (2009), among many others). Textural and compositional attributes are wide ranging. Directional fabrics such as foliation, lineation and lamination are often developed in the gneisses, schists, quartzites and tectonized rocks (Aigbedion 2006).

From hydrogeologic point of view, unweathered basement rock contains negligible groundwater; however, significant aquiferous unit can develop within the weathered overburden and fractured bedrock. It is this weathered and fractured zone, which forms potential groundwater zones. However, a number of factors that usually contribute to the weathering and development of fracture systems in the basement rocks can be summarized as follows (Jones 1985; Acworth 1987; Wright and Burgess 1992):

- $\quad$ presence and stress components of fractures; as conduit zones

- hydro-geomorphological conditions that dictate the influence of weathering agents

- hydro-climatic/temperature regimes that dictate chemical weathering pace

- mineral contents of the rock which affect the degree of weathering/overburden thickness.

Hence it can be summarized that the availability of groundwater in a typical basement setting like that of SWNigeria depends not only on the geology but also on the complex interactions of the various hydroclimatic and geomorphologic factors. Consequently, various techniques have been developed to locate favourable sites for the exploitation of groundwater resources within basement rocks. These include remote sensing geophysical methods and geomorphological studies (Wright and Burgess 1992; Lillesand and Kiefer 1994; Taylor and Howard 2000; MacDonald et al. 2005).

Groundwater condition in the study area

Assessment of previous studies revealed that the hydrogeological setting of the study area is characterized by weathered saprolite units with varied thickness over the different bedrock units such as porphyritic granites, granite-gneiss, migmatite, pegmatite and quartz-schist settings. Such setting suggests influence of rock types and mineralogy on the extent of fracturing and weathering. Consequently, groundwater occurrences in the study area are in localized, disconnected phreatic regolith aquifers, 
essentially under unconfined to semi-confined conditions (Tijani 1994). Nonetheless, groundwater occurrence in the study area can be categorized under two main units: area with highly weathered and/or fractured bedrock units and area with poorly weathered/sparsely fractured bedrock units.

In area with deep weathered regolith and highly fractured zones, groundwater occurrences usually depend on the thickness of the water-bearing rock; this rock can be gravely and fractured with possible quartz veins within the deep weathered zone of between $10 \mathrm{~m}$ to $30 \mathrm{~m}$. In the study area, these are characteristic of areas underlain by weathered crystalline and metamorphic rocks such as schist/ quartz-schist, fractured granite-gneiss and porphyritic granites as well as augen gneiss with vertical fracture zones. These are generally characterized by moderate to high yield of about $75 \mathrm{~m}^{3} /$ day and up to $>150 \mathrm{~m}^{3} /$ day. The borehole depth usually varies from 20 to $60 \mathrm{~m}$ while the saturated thickness varies from 20 to $35 \mathrm{~m}$ below the ground surface.

In areas where the weathered zone is thin or absent, groundwater is usually difficult to find due to widely spaced fractures and localized zone/pockets of weathered zone. In the study area, these are characteristic of areas underlain by crystalline and metamorphic rocks, especially migmatite and variably migmatized gneiss characterised by thin/shallow overburden unit of usually less than $10 \mathrm{~m}$ in thickness and low yield of generally less than $75 \mathrm{~m}^{3} /$ day. In such setting also the borehole depth varies from 20 to $30 \mathrm{~m}$ while saturated thickness varies from 8 to $20 \mathrm{~m}$ below ground surface

Nonetheless, towards the base of the weathered zone at the interface with the fresh bedrock, the permeability is usually high, allowing water to move freely due to low proportion of clayey materials. However, in such situations, deep-seated fractures are important source of groundwater and can sometimes provide appreciable water supplies, especially when tectonically controlled (MacDonald et al. 2005). Wells or boreholes that penetrate this horizon can usually provide sufficient water to sustain even hand pumps (Chilton and Foster 1995; MacDonald et al. 2005). It should be pointed out that due to the complex interactions of the various factors affecting weathering in a typical basement complex setting like the study area, the distribution of groundwater potential zone can be erratic and may not be present at all in some locations.

The study of Allichi (2007) which involved characterization of weathered overburden revealed estimated overburden thickness using geoelectrical VES surveys to be from 3.8 to $50 \mathrm{~m}$ with mean value of about $20 \mathrm{~m}$ as dictated by bedrock types. These values are within the range of values obtained for similar Basement Complex terrains of Africa. Furthermore, it was observed that areas with thin/shallow overburden coincided mostly with areas underlain by variably migmatized gneiss complex, while area with thicker overburden unit coincided with area mainly underlain by schist. However, quartzite/quartzschist setting coincided with areas of moderate to shallow overburden thickness.

In summary, the varied thickness and the isolated pockets of the weathered overburden units also confirm the localized nature of weathered basement aquifers under crystalline basement setting. The implication of this lies in the fact that there is the need for careful characterization and delineation of areas of possible fracturing and deep weathering as aquiferous zone in respect of groundwater developments in Basement Complex settings of the study area. Therefore, the present study addresses the aspect of characterization of the groundwater potential using integrated GIS, RS and MCDA techniques in conjunction with conventional hydrological and hydrogeological data.

\section{Materials and methods}

For the study, existing hydrogeological and relevant data on soils, geological/lithological units, structural features, geomorphologic and climatic conditions of the study area were collated. The overall study concept involved integration of nine thematic layers of conventional geology, soil, drainage and lineament maps, rainfall data as well as remotely sensed data of land-use, slope and geomorphology using both ArcGIS 10.0 and Idrisi Selva 17.0 GIS software. All of the map themes were presented in UTM Projection Zone 31, Datum WGS84 with 30 metre resolution.

\section{Preparation of thematic layers}

The analogue geological and lineament maps of the study area obtained from Nigeria Geological Survey Agency (NGSA) with scale 1:100,000 were georeferenced and digitized in ArcGIS 10.0 software platform. Lineaments are manifestation of linear features that can be identified directly on the rock units or from remote sensing data while lineaments and their intersections play a significant role in the occurrence and movement of groundwater resources in crystalline rocks (Rao 2006; Prasad et al. 2008). The presence of lineaments may act as a conduit for groundwater movement which results in increased secondary porosity and, therefore, can serve as groundwater potential zone (Obi Reddy et al. 2000). Lineament density map was computed in and expressed in terms of length of the lineament per unit area $\left(\mathrm{km} / \mathrm{km}^{2}\right)$ in the GIS software.

In addition, land use/land cover (LULC) plays important role in the occurrence and development of groundwater. 
LULC map for the study was extracted from a mosaicked Landsat ETM imagery of February 16, 2010 series through supervised classification of the false colour composite of the band 4, 3 and 2 to obtain the land use category in Idrisi Selva software platform. Also soil zone generally has significant role on the amount of infiltrating water and hence influences groundwater recharge. The rate of infiltration largely depends on the grain size and related hydraulic characteristics of the soils. For this study, soil map of the study area was clipped from Soil Unit FAO/UNESCO/ISRIC map of Nigeria.

Geomorphology reflects various landform and topographical features. Surface water is one of the important geomorphological agents in the development and shaping of landscapes and landforms; thus hydrogeomorphological studies are of importance in the planning and execution of groundwater exploration. Slope, on the other hand, is an aspect of geomorphologic features which controls the infiltration and recharge of groundwater system: thus the nature of slope alongside other geomorphic features can give indication of groundwater prospect of an area. Therefore, Digital Elevation Model (DEM) of the Advanced Spaceborne Thermal Emission and Reflection Radiometer (ASTER) of 2002 at $30 \mathrm{~m}$ resolution were used to generate the geomorphology and slope thematic maps using assigned threshold values (Saraf and Choudhary 1998; Rao and Jugran, 2003; Prasad et al. 2008).

Generally, rainfall represents direct recharge source of groundwater in the study area while the development and exploitation of groundwater is through open dug-wells and shallow boreholes. As mentioned earlier, groundwater occurs in the weathered zone under unconfined conditions as well as in the fractured zone semi-confined conditions in some cases. Mean annual rainfall data for 30 years were obtained from seven stations of the Nigerian Meteorological Agency (NIMET) stations located in the study area (Fig. 2). The data were processed using the Thiessen polygon technique in the ArcGIS 10.0 software platform to obtain the spatial rainfall pattern of the study area. Thiessen polygons define the individual 'regions of influence' around each of a set of points such that any location within particular polygon is nearer to that polygon's point than to any other point, and, therefore, has the same value (Heywood et al. 1998). This method is commonly used in the analysis of climatic data when the local observations are not available and so the data from the nearest weather stations are used.

Drainage pattern reflects the characteristic of surface as well as subsurface formation. Drainage map was obtained from DIVAGIS (http://www.diva-gis.org) and subsequently processed to obtain the drainage density map. Drainage density map delineation was followed by the division of study area into micro-watersheds (Singh et al.

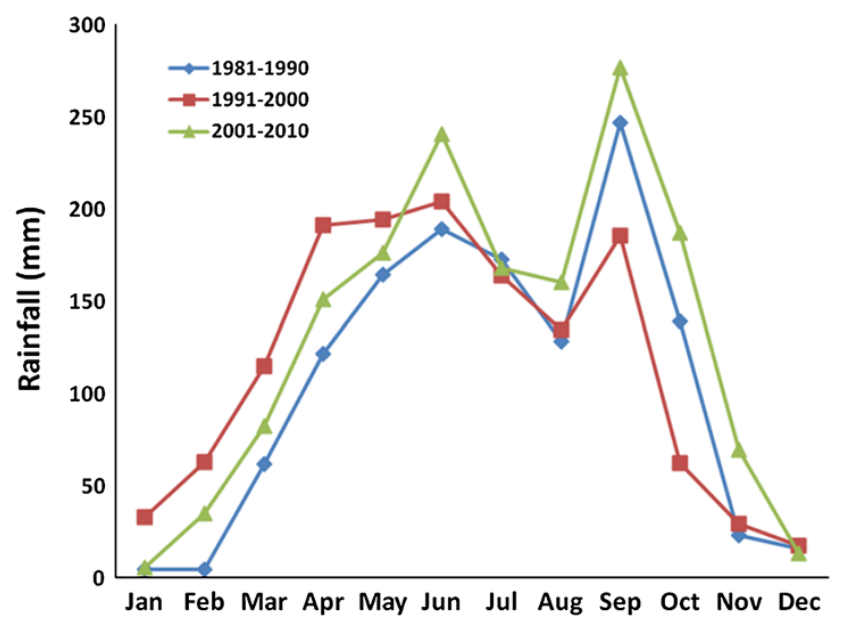

Fig. 2 Trend of mean annual rainfall within the study area for 30 years

2013). Intersection of micro-watersheds and drainage layer was used for the calculation of drainage density for each of the micro-watershed expressed in terms of the length of channels per unit area $\left(\mathrm{km} / \mathrm{km}^{2}\right)$ in the ArcGIS 10.0 software platform. The drainage density values thus obtained were reclassified to prepare a drainage density map of the study area. Furthermore, water bodies are fewer in areal extent and are distributed sporadically over the study area; thus the buffered areas are considered more suitable zone for groundwater occurrence than areas beyond. Consequently, the drainage map was used to obtain the proximity to water bodies map using the buffering option of ArcGIS 10.0 software.

Subsequent to the preparation of all the different thematic maps (including rainfall, slope, drainage density, soil, land use, slope, geology and lineament thematic maps) with varied attributes, the maps were converted into raster format and then assigned suitable weights in order of their hierarchy in groundwater potentiality using the analytic hierarchy process (AHP) (Saaty 1980, 1992). All the normalized weighted thematic layers were integrated and processed in ArcGIS 10.0 platform to demarcate the potential groundwater zone in the study area. The details of the procedures adopted for this study is summarzed graphically as flow-chart in Fig. 3 while further details on the AHP and weight assignments are highlighted in the following section.

Analytical hierarchy process, weights assignments and integration of thematic maps

The analytic hierarchy approach (AHP) developed by Saaty $(1980,1986,1992)$ was used in this study as a decisionaiding method to finalize the weights assigned to different themes and their respective features used in deciphering 


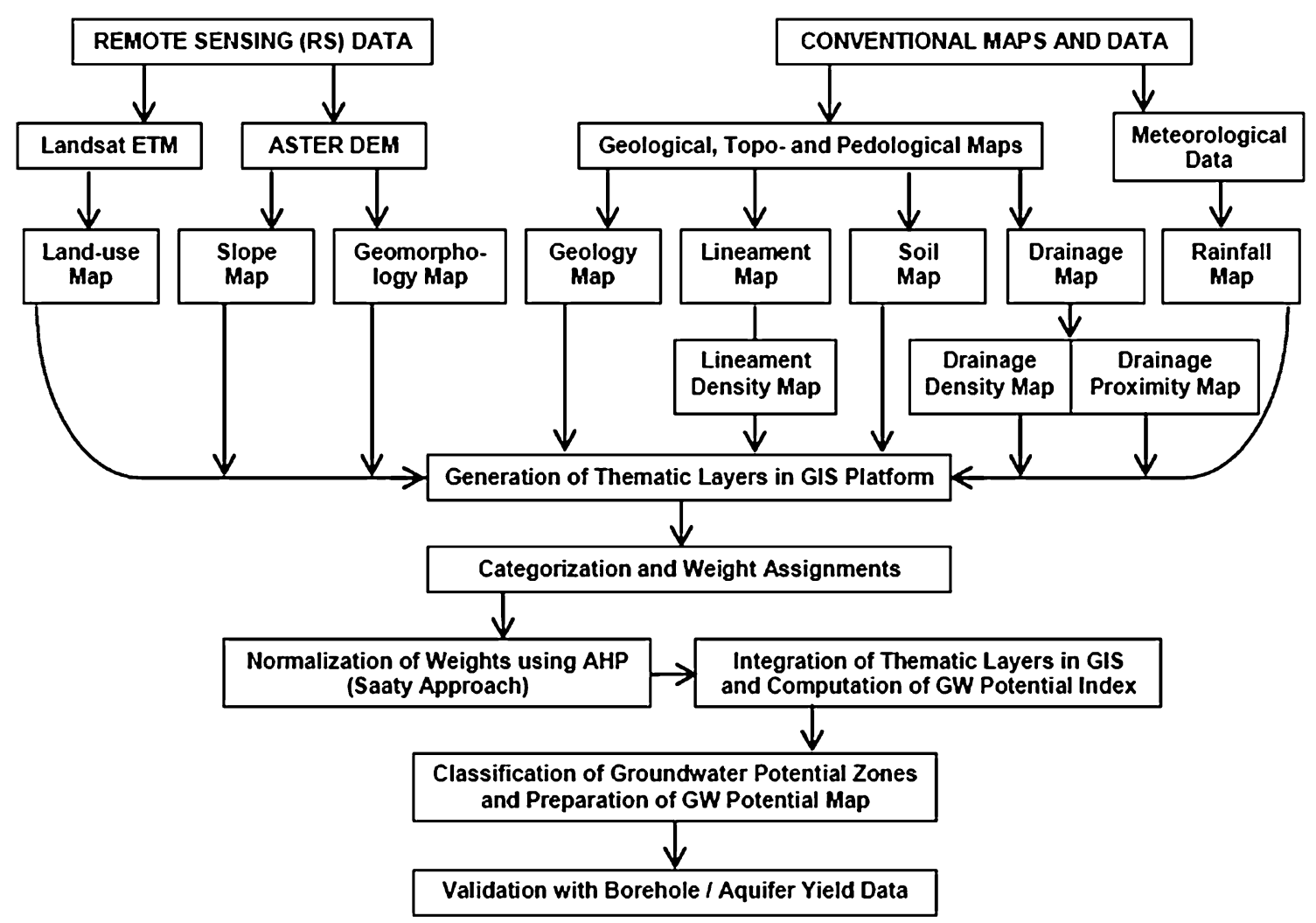

Fig. 3 Flowchart for delineating potential groundwater zones in SW-Nigeria using, MCDA, GIS and RS techniques

groundwater potentiality. AHP is a simple mathematical matrix-based technique that allows users to assess the relative weight of multiple criteria in an intuitive manner. It allows efficient group decision-making, where group members can use their experience, values and knowledge to breakdown a problem into a hierarchy and solve it by AHP steps (Chowdhury et al. 2009). It also incorporates systematic checks on the consistency of judgments, which is one of the strongest points over the other multi-attribute value processes.

The attributes of each of the thematic maps employed in this study were assigned weightage of $1-4$, depending on the relative contribution to the occurrence and movement of groundwater. In terms of groundwater potentiality the weightage factor 1 denotes low/poor, 2 implies moderate, 3 represents good and 4 denotes high groundwater potentiality. The weightage employed is in accordance with the respective importance of the map theme to groundwater occurrence following the approach of Saraf and Choudhary (1998), Rao and Jugran (2003), Prasad et al. (2008), Jha et al. (2010), Machiwal et al. (2011), Mukherjee et al. (2012) and Singh et al. (2013). The weights of the individual themes and their associated features were then normalized by the Saaty's AHP and the eigenvector technique was used to reduce the subjectivity associated with the assigned weights (Table 1). Further, the pair-wise comparison matrices of the assigned weights of the different thematic maps were constructed and computed (Table 2) using the Idrisi Selva software.

The Consistency Index (CI) of the assigned weights was calculated following the procedure suggested by Saaty (1980, 1992) while the Consistency Ratio, which indicates the probability that the matrix ratings were randomly generated, was also computed using the values of Random Consistency Index (RI) which is the average value of CI for random matrices using the Saaty scale obtained by Forman $(1983,1990)$ based on the following relations:

$$
\begin{aligned}
& \text { Consistency Index }=\left(\lambda_{\max }-n\right) /(n-1), \\
& \text { Consistency Ratio }=\mathrm{CI} / \mathrm{RI}
\end{aligned}
$$

where $n$ is the number of criteria or factors

It should be noted that the $\mathrm{CR}$ value should be less than 0.10 for consistent weights; otherwise, corresponding weights should be re-evaluated to avoid inconsistency (Saaty 1980, 1986, 1992). For this study, the CR was estimated to be 0.02 which is far below the threshold consistency value of 0.10 . Furthermore, each of the thematic maps was then assigned weight in the range of 1-9 according to Saaty's scale of assignment (Table 1), which depicts the relative importance of the respective themes to groundwater availability. The weights assigned to the respective thematic maps as presented in Table 3 indicate 
Table 1 Saaty's scale for assignment of weights and its interpretation showing the pair-wise comparison process (Saaty 1980, 1986, 1992)

\begin{tabular}{|c|c|c|c|c|c|c|c|c|}
\hline \multicolumn{4}{|c|}{ Less important } & \multirow{2}{*}{$\begin{array}{l}\text { Equally important } \\
\text { Equally }\end{array}$} & \multicolumn{4}{|c|}{ More important } \\
\hline Extremely & Very strongly & Strongly & Moderately & & Moderately & Strongly & Very strongly & Extremely \\
\hline $1 / 9$ & $1 / 7$ & $1 / 5$ & $1 / 3$ & 1 & 3 & 5 & 7 & 9 \\
\hline
\end{tabular}

2, 4, 6 and 8 are intermediate values that denotes comprise

Table 2 The pair-wise comparison matrices table of the different themes

\begin{tabular}{|c|c|c|c|c|c|c|c|c|c|}
\hline Themes & GG & $\mathrm{RF}$ & ST & GM & LU & SL & LD & DD & DP \\
\hline \multicolumn{10}{|l|}{ Geology (GG) } \\
\hline & 1 & & & & & & & & \\
\hline Rainfall (RF) & 1 & 1 & & & & & & & \\
\hline Soil Type (ST) & 1 & 1 & 1 & & & & & & \\
\hline Geomorphology (GM) & 1 & 1 & 1 & 1 & & & & & \\
\hline Landuse (LU) & 1 & 1 & 1 & 1 & 1 & & & & \\
\hline Slope (SL) & $1 / 2$ & $1 / 2$ & 1 & 1 & 1 & 1 & & & \\
\hline Lineament density (LD) & $1 / 3$ & $1 / 3$ & $1 / 2$ & 1 & 1 & 1 & 1 & & \\
\hline Drainage density (DD) & $1 / 4$ & $1 / 5$ & $1 / 4$ & $1 / 2$ & $1 / 3$ & $1 / 2$ & 1 & 1 & \\
\hline Drainage proximity (DP) & $1 / 9$ & $1 / 8$ & $1 / 7$ & $1 / 6$ & $1 / 5$ & $1 / 4$ & $1 / 3$ & $1 / 2$ & 1 \\
\hline
\end{tabular}

that geology was ranked the dominant factor with a normalized weight value of 0.1745 while proximity to water bodies is the least accounted factor with a normalized weight of 0.0224 for groundwater occurrence in the study area. The summary of the assigned and normalized weights of the features of the different thematic layers alongside with ranking and coverage areas is presented in Table 4

On the final analysis, nine different thematic maps were integrated using ArcGIS 10.0 software to generate the groundwater potential index (GWPI) for the study area. The index was computed by the integration of the total normalized weights of different polygons using equation stated below. This technique is associated with the study of locations of geographic phenomena together with their spatial dimension and associated attributes (Prasad et al., 2008).

$$
\begin{aligned}
\mathrm{GWPI}= & \left(\mathrm{GM}_{w} \mathrm{GM} w_{\mathrm{i}}+\mathrm{GG}_{w} \mathrm{GG} w_{\mathrm{i}}+\mathrm{LULC}_{w} \mathrm{LULC} w_{\mathrm{i}}\right. \\
& +\mathrm{DD}_{w} \mathrm{DD} w_{\mathrm{i}}+\mathrm{SL}_{w} \mathrm{SL} w_{\mathrm{i}}+\mathrm{LD}_{w} \mathrm{LD} w_{\mathrm{i}} \\
& +\mathrm{ST}_{w} \mathrm{ST} w_{\mathrm{i}}+\mathrm{RF}_{w} \mathrm{RF} w_{\mathrm{i}}+\mathrm{DP}_{w} \mathrm{DP} w_{\mathrm{i}}
\end{aligned}
$$

where GG is the geology, GM is geomorphology, LULC is landuse/land cover, DD is drainage density, SL is slope, LD is lineament density, ST is soil type, RF is rainfall, DP is drainage proximity, $w$ is normalized weight of a theme and $w_{\mathrm{i}}$ is the normalized weight of individual classes.

Thus, using raster calculator tools in ArcGIS platform, a composite groundwater potential index (GWPI) for the study area was generated on the basis of which the overall groundwater potential map was produced. Finally, well/ borehole data (e.g. yield, depths and saturated thickness)
Table 3 Weights of the thematic maps of the potential groundwater

\begin{tabular}{lll}
\hline Themes & Assigned weights & Normalized weights \\
\hline Geology & 9 & 0.1745 \\
Rainfall & 8 & 0.1717 \\
Soil & 7 & 0.1471 \\
Geomorphology & 6 & 0.1284 \\
Landuse & 5 & 0.1256 \\
Slope & 4 & 0.1020 \\
Lineament density & 3 & 0.0802 \\
Drainage density & 2 & 0.0481 \\
Drainage proximity & 1 & 0.0224 \\
\hline
\end{tabular}

were collated from existing wells in the study area. These data were used for the purpose of validation of the proposed groundwater potential map, as a useful guide for a quick assessment of groundwater occurrence on regional scale in the study area.

\section{Results and discussion}

\section{Geology/lithology}

The study area is underlain by the Basement Complex rocks of southwestern Nigeria which are integral part of the Precambrian unit of the West African Craton. Precambrian Basement Complex terrain of SW-Nigeria comprises igneous and metamorphic rock units (migmatite gneisses, 
Table 4 Assigned and normalized weights of the features of themes for the delineation of the groundwater potentials in the study area

\begin{tabular}{|c|c|c|c|c|c|c|}
\hline Categories & Criterion & Weight & Normalized weight & Rank & Area $\left(\mathrm{km}^{2}\right)$ & Percentage area \\
\hline \multirow[t]{4}{*}{ Geology } & Migmatite gneiss & 1 & 0.1307 & 0.175 & $71,603.5$ & 67.69 \\
\hline & Granitic rocks & 2 & 0.1678 & & $12,797.6$ & 12.10 \\
\hline & Schist and metasediments & 3 & 0.2200 & & $16,321.3$ & 15.43 \\
\hline & Quartzite & 4 & 0.4814 & & $5,055.6$ & 4.78 \\
\hline \multirow[t]{4}{*}{ Rainfall } & $1,164-1,296 \mathrm{~mm}$ & 1 & 0.1307 & 0.172 & $35,926.9$ & 33.96 \\
\hline & $1,296-1,452 \mathrm{~mm}$ & 2 & 0.1678 & & $29,292.9$ & 27.69 \\
\hline & $1,453-1,512 \mathrm{~mm}$ & 3 & 0.2200 & & $29,782.9$ & 28.16 \\
\hline & $1,512-1,776 \mathrm{~mm}$ & 4 & 0.4814 & & $10,775.3$ & 10.19 \\
\hline \multirow[t]{3}{*}{ Soil } & Clayey loam & 1 & 0.2098 & 0.147 & $57,005.0$ & 53.89 \\
\hline & Loam & 2 & 0.3021 & & $38,398.6$ & 36.30 \\
\hline & Sand loam & 3 & 0.4991 & & $10,374.4$ & 9.81 \\
\hline \multirow[t]{4}{*}{ Geomorphology } & Inselbergs & 0 & 0 & 0.128 & $9,688.8$ & 9.16 \\
\hline & Ridges & 1 & 0.1700 & & $39,466.4$ & 37.31 \\
\hline & Plains & 3 & 0.2805 & & $32,623.6$ & 30.84 \\
\hline & Lowlands & 4 & 0.6495 & & $23,999.2$ & 22.69 \\
\hline \multirow[t]{4}{*}{ Land-use } & Water bodies & 0 & 0 & 0.126 & 222.9 & 0.21 \\
\hline & Settlements & 1 & 0.2105 & & $25,582.1$ & 24.18 \\
\hline & Soil & 2 & 0.3134 & & $32,071.7$ & 30.32 \\
\hline & Vegetations & 3 & 0.4761 & & $47,901.3$ & 45.28 \\
\hline \multirow[t]{4}{*}{ Slope } & $<6.25$ & 4 & 0.4814 & 0.102 & $102,201.1$ & 96.62 \\
\hline & $6.25-12.0$ & 3 & 0.2200 & & $2,795.7$ & 2.64 \\
\hline & $12.1-18.5$ & 2 & 0.1678 & & 517.2 & 0.49 \\
\hline & $>18.5$ & 1 & 0.1307 & & 264.0 & 0.25 \\
\hline \multirow[t]{4}{*}{ Lineament density } & $0-0.04$ & 1 & 0.1307 & 0.080 & $30,419.6$ & 28.75 \\
\hline & $0.05-0.09$ & 2 & 0.1678 & & $37,008.5$ & 34.99 \\
\hline & $0.10-0.16$ & 3 & 0.2200 & & $28,418.2$ & 26.89 \\
\hline & $0.17-0.35$ & 4 & 0.4814 & & $9,931.4$ & 9.388 \\
\hline \multirow[t]{3}{*}{ Drainage density } & $0-0.5$ & 3 & 0.4991 & 0.048 & 10,497 & 9.92 \\
\hline & $0.5-1$ & 2 & 0.3021 & & 54,112 & 51.16 \\
\hline & $>1.0$ & 1 & 0.2098 & & 41,173 & 38.92 \\
\hline \multirow[t]{3}{*}{ Water body proximity } & $<75 \mathrm{~m}$ & 3 & 0.4991 & 0.022 & $16,109.4$ & 15.23 \\
\hline & $75-150 \mathrm{~m}$ & 2 & 0.3021 & & $16,342.5$ & 15.45 \\
\hline & $>150 \mathrm{~m}$ & 1 & 0.2098 & & $73,324.2$ & 69.32 \\
\hline
\end{tabular}

granites, quartzites, schist and metasediments). The quartzite and granite gneiss settings often form elevated topographic ridges and inselbergs (Elueze 1995), while the schist and meta-sediment settings form low-lying areas (Fig. 4).

In line with the complexity of the tectonic history of the Basement Complex rocks, a number of authors have described the geology and classification of the Basement rocks of southwestern Nigeria. The earliest systematic geological work is that of Jones and Hockey (1964) in their report on the geology of southwestern Nigeria, where five groups of rocks were recognized. Oyawoye (1970) classified the Basement rocks into four groups while Rahaman (1976) recognized five major groups of rocks. Odeyemi
(1976), however, classified the main rocks of the Basement Complex into four groups:

(a) The migmatite-gneiss complex

(b) The meta-sediments (composed of schist, calc-gneiss, quartzite and meta-conglomerate.

(c) The porphyritic older granite

(d) Miscellaneous rock types, mostly post orogenic such as aplites, pegmatite and dolerite dykes.

As highlighted earlier, the geology of the study area is dominated by the Precambrian basement rock units consisting of igneous and metamorphic rock units, i.e. migmatite gneisses, granites, schist/metasediments and quartzites. The 


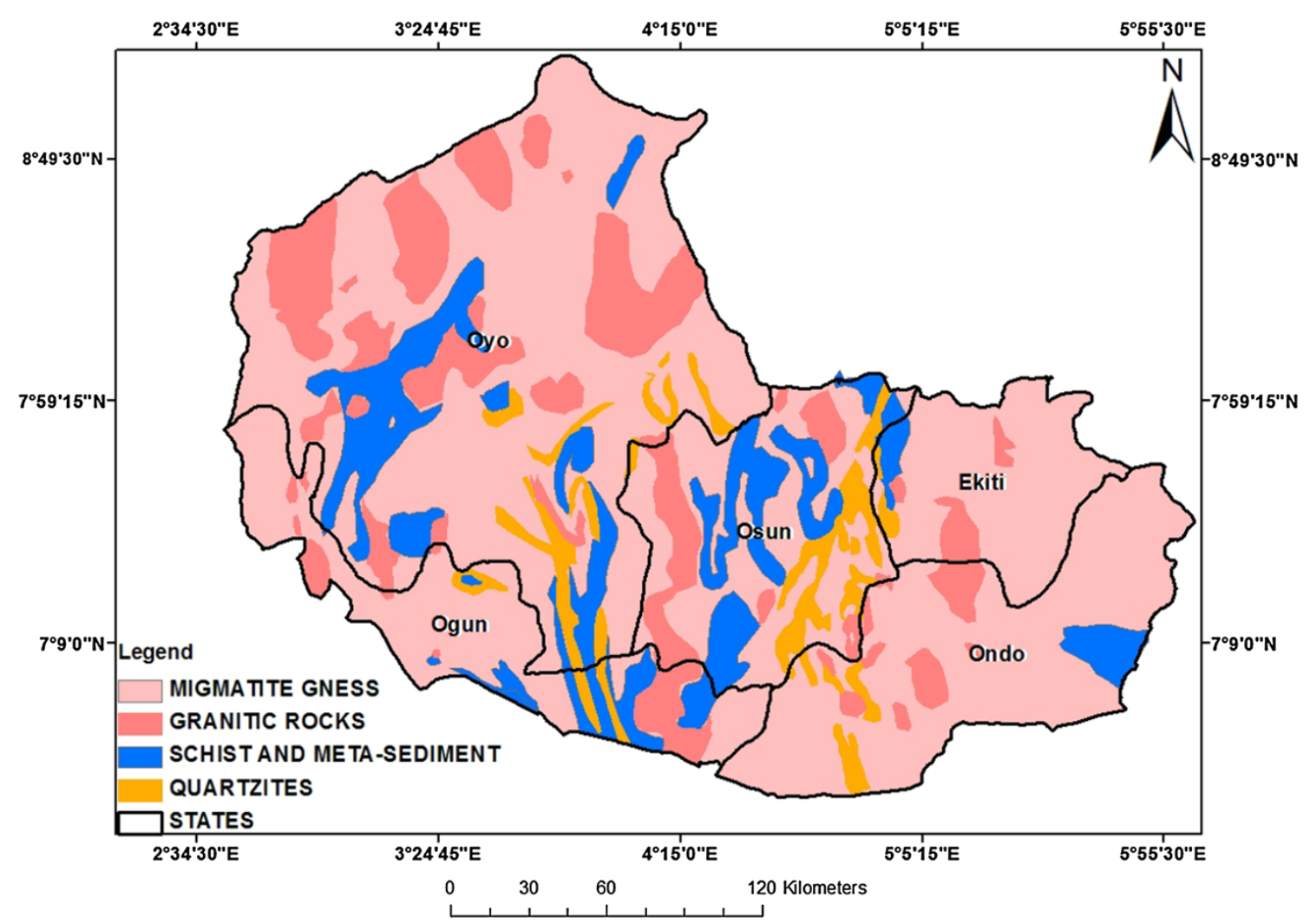

Fig. 4 Geological map of the study area (based on the NGSA map of Nigeria, with scale 1:100,000)

migmatite gnesiss and granitic rocks are widespread over the study area covering about $71,603.5 \mathrm{~km}^{2}(68 \%)$ and $12,797.6 \mathrm{~km}^{2}$ (12\%), respectively. Schist/metasediments and quartzites are limited to the central and western parts of the study area covering about $16,321.3 \mathrm{~km}^{2}(15 \%)$ and $5,055.6 \mathrm{~km}^{2}(5 \%)$, respectively.

Usually, massive unfractured lithologic units in Basement Complex setting has little influence on groundwater availability except in cases with secondary porosity through the development of weathered overburden and fractured bedrock units, which form potential groundwater zones. Hence, on the basis of the presence and nature of the weathered regolith units and fracture systems, appropriate weights are assigned to the different rock units in the study area. The weightage in terms of increasing groundwater potentiality is in the order of migmatite gneisses $(0.13)<$ granites $(0.17)<$ schist/metasediments $(0.22)<$ quartzites $(0.48)$.

Lineaments and lineament density

The study area is criss-crossed with lineaments consequent to a number of tectonic activities in the past. Three prominent directions identified are N-S, NE-SW and NWSE trends. Usually, lineament density map is a measure of quantitative length of linear feature per unit area which can indirectly reveal the groundwater potentials as the presence of lineaments usually denotes a permeable zone. For most of the study area, the lineament density varies from less than $0.04 \mathrm{~km} / \mathrm{km}^{2}$ which covers a total area of $30,419.6 \mathrm{~km}^{2}$ (29\%) to $0.35 \mathrm{~km} / \mathrm{km}^{2}$ with total area of $9931.4 \mathrm{~km}^{2}$ (9\%) (Fig. 5). Though the lineaments are widespread across the study area, however, the distribution of lineaments suggests geologic control with areas underlain by migmatite gneiss and granites having relatively lower lineament density (of $0.04-0.09 \mathrm{~km} / \mathrm{km}^{2}$ ) compared with areas underlain by metasediments and quartzites with higher lineament densities of $0.16-0.35 \mathrm{~km} / \mathrm{km}^{2}$ ).

Thus areas with higher lineament density are regarded as good for groundwater development. Consequently, higher weightage of 0.4814 was assigned to area with high density of lineaments, which are closely associated with area underlain by meta-sediments and quartzites while a low weightage of 0.1307 was assigned to areas underlain by migmatite with low lineament density.

\section{Geomorphology}

In this study, four main geomorphological units were identified and delineated with respect to the respective elevations from the RS imagery of the study area (Fig. 6). These are lowlands and plains representing weathered lowlying piedmont plains covering about $23,999.17 \mathrm{~km}^{2}$ 


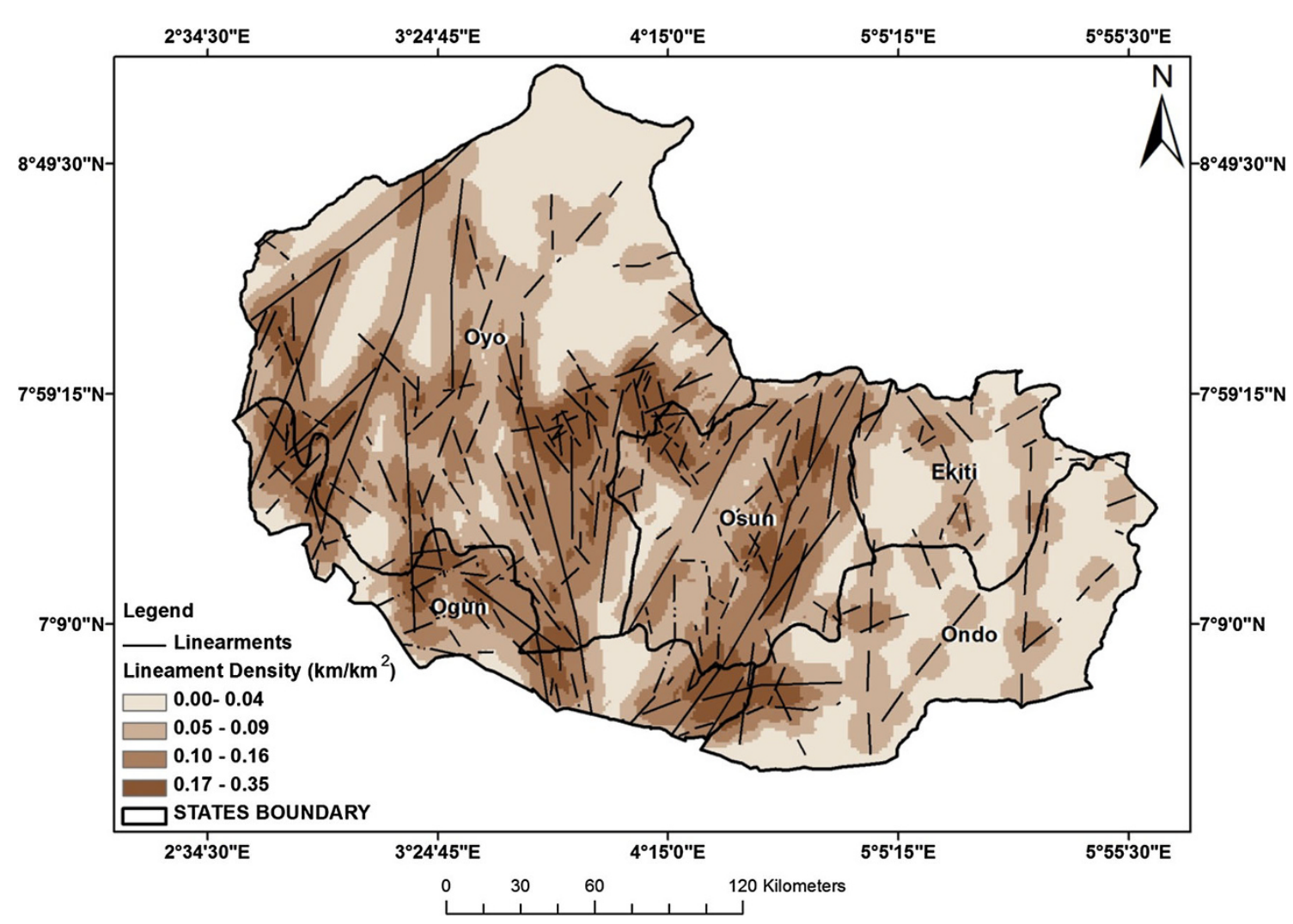

Fig. 5 Lineament density map of the study area

$(22.7 \%)$ and $32,623.59 \mathrm{~km}^{2}(30.8 \%)$ of the study area, respectively. Plains are geographical feature that are flat or gently rolling while lowlands are defined for this purpose of this study as a geographical piece of land that are low in terms of its height above mean sea level.

On the other hand, ridges and inselbergs represent a chain of low-lying ridges or hills that form a continuous elevated crest constituting about $39,466.42 \mathrm{~km}^{2}$ (37\%) and $9,688.82 \mathrm{~km}^{2}(9.2 \%)$ of the study area, respectively. These geomorphological features based on the respective significance with respect to groundwater occurrence are weighted and classified with increasing order of groundwater potentiality as inselbergs $(0)<$ ridge $(0.17)<$ plain $(0.28)<$ lowland $(0.65)$. A closer look at the classification revealed that the lowlands and plains are to the southern part of the study area representing the middle and lower course of the drainage systems while the ridges and inselbergs are to the north occupying the watershed areas.

\section{Slope}

As an aspect of geomorphologic features, slope is one of the factors controlling the infiltration and recharge of groundwater system: thus the nature of slope alongside other geomorphic features can give indication of groundwater prospect of an area. In the low slope area the surface runoff is low allowing more time for infiltration of rainwater, while high slope area enhances high runoff with short residence time for infiltration and recharge.

In this study, the slope thematic map as presented in Fig. 7 revealed slopes ranging from less than $6.25 \%$ to more than $18.5 \%$. The wide range and distribution of the slopes in the study area is an indication of varied degree of run-off and recharge which imply varied groundwater potential characteristic of crystalline basement setting.

About $102,201 \mathrm{~km}^{2}$ is covered by less than $6 \%$ slope, which signifies nearly flat surfaces to very gentle slopes and constitutes about $96 \%$ of the study area while about $2,796 \mathrm{~km}^{2}$ has $6-12 \%$ slope (gentle to slight slopes) making up of $2.6 \%$. Areas with $12-18 \%$ slope (slightly steep) and greater than $18 \%$ slope (steep slopes) cover area of 517.19 and $264.1 \mathrm{~km}^{2}$, respectively, both of which constitute less than $1 \%$ of the total area. Consequently, based on the influence of slope in respect of infiltration and groundwater recharge, areas with less than $6 \%$ slope (i.e. nearly flat surfaces to very gentle slopes) which constitutes about $96 \%$ of the study area were rated higher in terms of groundwater potentiality with weighted factor of 0.48 compared with areas with slope greater than $18 \%$ with weighted factor of 0.13 . The overall implication is that the southern part of the study area is dominated by low slope 


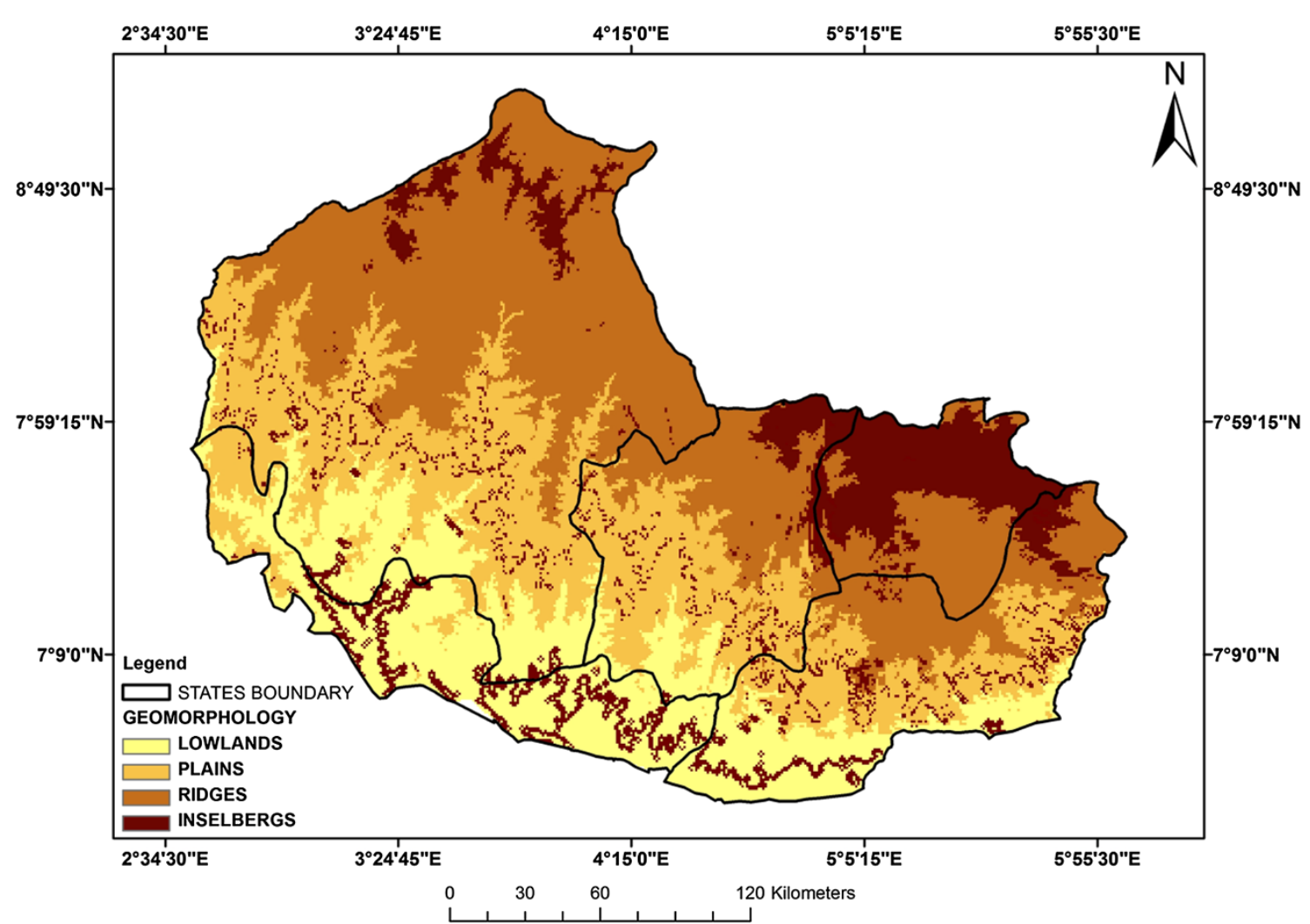

Fig. 6 Geomorphology map of the study area

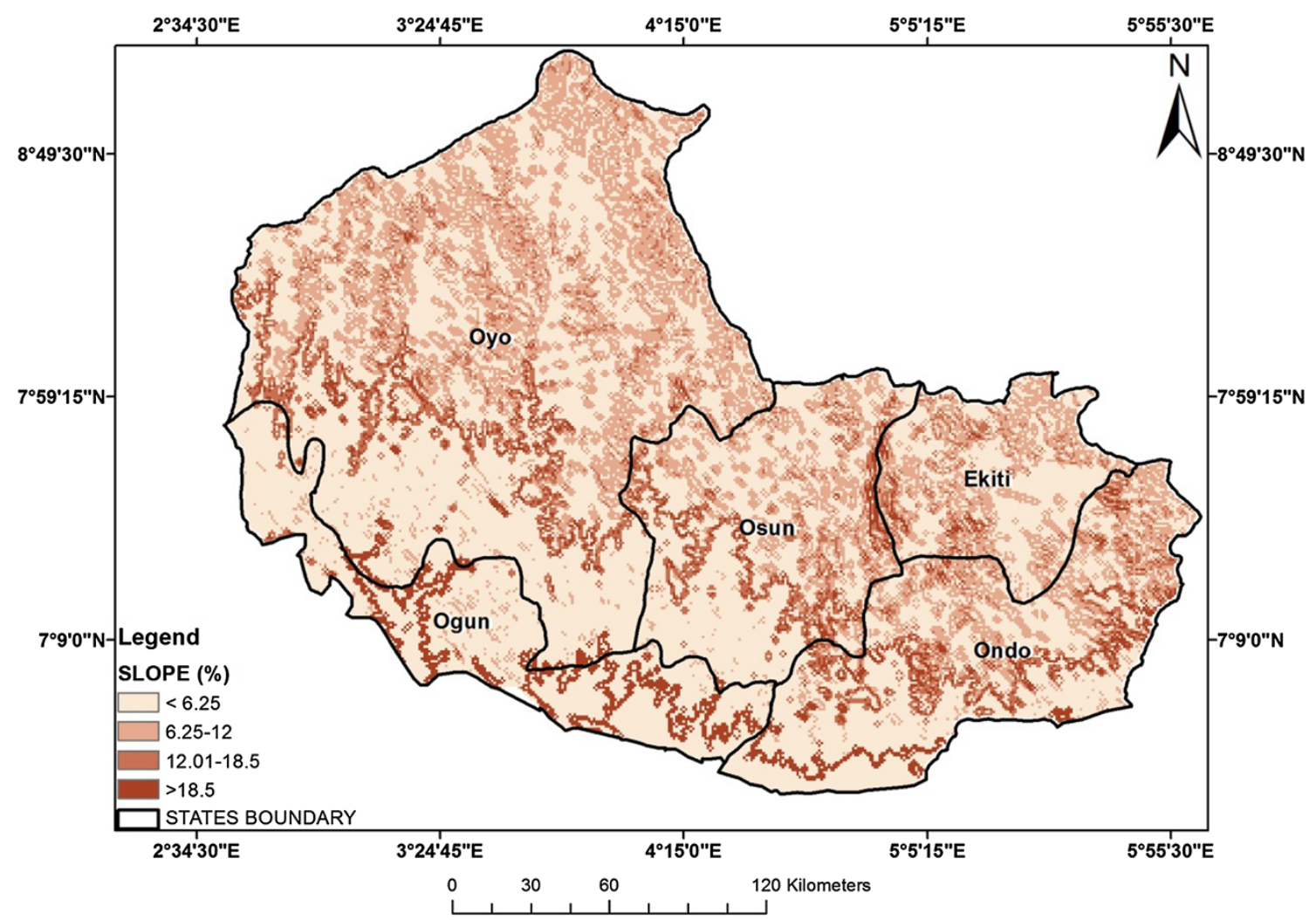

Fig. 7 Slope map of the study area 
$(<6 \%)$ which incidentally also represents the area dominated by the lower course of the drainage channels compared with the northern part of the study area that represents watershed areas dissected by the upper channels of the drainage systems.

\section{Drainage density}

The area of very high drainage density represents more closeness of drainage channels and vice versa; hence, the higher the drainage density, the greater the runoff while the lesser the drainage density, the lower the run-off and the higher the probability of recharge or potential groundwater zone. Furthermore, it has been suggested that a measure for permeability is drainage density (i.e. total length of drainage channels per unit area), in the sense that permeable conditions are associated with low drainage density and vice versa (Meijerink 2007). Most of the drainage originates from the granitic hills and inselbergs in the northern part of the study area and the drainage pattern is generally dendritic, typical of crystalline basement terrain.

The estimated drainage density in the study area as presented in Fig. 8 revealed moderately dense drainage network with values of 0.5 to greater than $1 \mathrm{~km} / \mathrm{km}^{2}$. The high drainage density areas which constitute about $41,173 \mathrm{~km}^{2}$ (39\% of the total area) are weighted relatively lower (0.2098) compared with low drainage density areas that are weighted higher with value of 0.499 and constitute about $10,497 \mathrm{~km}^{2}(9.9 \%)$. However, the generally moderate to high drainage density implies low or moderate infiltration and recharge potentials for about $90 \%$ of the study area. Hence, low overall percentage contribution of the drainage density $(2.1 \%)$ to the overall groundwater potential.

\section{Rainfall}

The rainfall distribution in the study area ranges from 1,160 to $1,775 \mathrm{~mm}$ suggesting a humid tropical terrain with the entire study area receiving more than $1,000 \mathrm{~mm}$ of rainfall annually (Fig. 9).

Areas with higher amount of rainfall have weightage factor of 0.48 signifying very good groundwater potential which covers about $10,775.34 \mathrm{~km}^{2}(10.2 \%)$ while areas with the lowest amount of rainfall have weightage factor of 0.13 , suggesting poor groundwater potentiality and represent about $35,926.88 \mathrm{~km}^{2}$ (34\%). A closer look at the rainfall thematic map revealed the northern part have relatively lower rainfall $(<1,556 \mathrm{~mm})$ which can be attributed to the influence of the receding rain-bearing South-West trade wind from the southern coastal boarders. Generally, the southern part received high rainfall $(>1,556-1,616 \mathrm{~mm})$; however, a pocket of higher rainfall of $>1,616 \mathrm{~mm}$ in the south can be attributed to the effect of localized orographic rainfall induced by the elevated inselbergs and quartzite ridges.

\section{Soil zones}

Fine-grained soils limit infiltration due to apparently low permeability unlike coarse-grained soil materials where water can infiltrate easily because of high permeability. In this study, three main soil units were identified: clayey loam soils, loamy soils and sandy loam soils covering $57,005.03 \mathrm{~km}^{2}(53.8 \%), 38,398.55 \mathrm{~km}^{2}$ (36.3\%) and $10,374.43 \mathrm{~km}^{2}(9.8 \%)$ of the total study area, respectively, as shown in Fig. 10.

Given the relationship between the sand content/coarsegrained materials and permeability, higher weightage was given to soils with relatively higher permeability; thus sandy loam units are assigned a weightage factor of 0.48 compared with that of clayey loam with a factor of 0.21 indicating lower groundwater potentials, while loam soils have intermediate value of 0.30 representing moderate groundwater potential.

\section{Land use/land cover (LULC)}

Land use/land cover plays important role in the occurrence and development of groundwater. Consequently, the identified land use/land cover features for this study from the thematic map are vegetation area (cropland and forest plantation), water bodies (stream and lakes), built-up areas/ settlements as well as open bare soils surfaces/outcrops areas (Fig. 11).

Vegetated area, as the dominant land use types, covered an area of about $47,901.30 \mathrm{~km}^{2}$ representing about $45 \%$ of the total area followed by open bare soil surfaces covering $32,071.67 \mathrm{~km}^{2}(30 \%)$. Settlements and built-up areas constitute only $25,582.13 \mathrm{~km}^{2}(24 \%)$ while about and $222.89 \mathrm{~km}^{2}(<1 \%)$ are covered by water bodies in the form of streams and lakes. Coupled with generally high amount of precipitation $(>1,000 \mathrm{~mm})$, the distribution of land-use is expected to enhance groundwater recharge depending on the underlying soil and geologic conditions.

Proximity to water bodies

The 75-m buffered area around the surface water bodies was considered as a more suitable zone for groundwater occurrence than the areas beyond (Fig. 12). This is based on the possible or anticipated surface-groundwater interactions.

In this study, three buffers zones were identified: $<75$, $75-150$ and $>150 \mathrm{~m}$ with a total area of $16,109.4 \mathrm{~km}^{2}$ $(15.2 \%), \quad 16, \quad 342.5 \mathrm{~km}^{2}(15.4 \%)$ and $73,324.2 \mathrm{~km}^{2}$ 


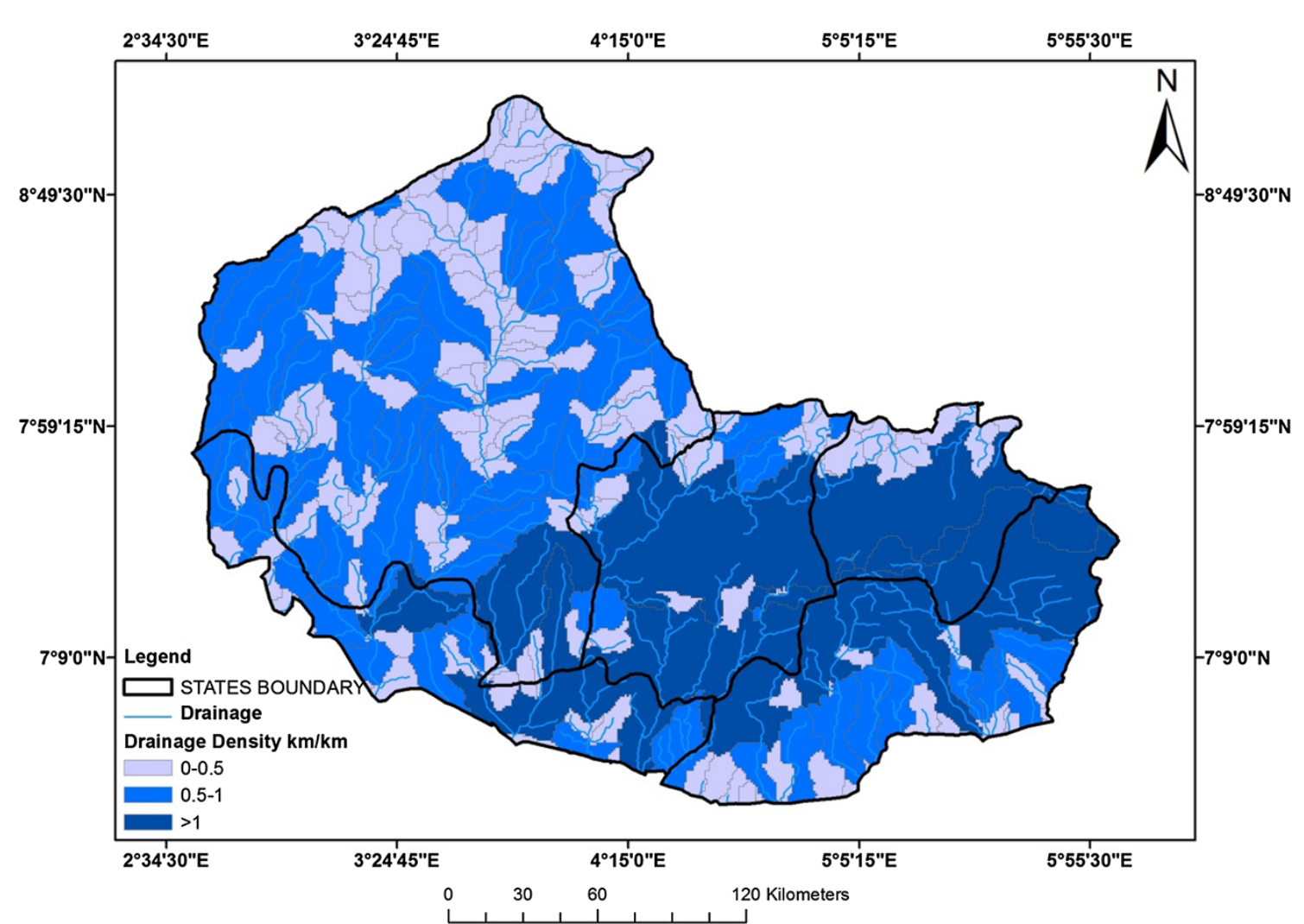

Fig. 8 Drainage density map of the study area

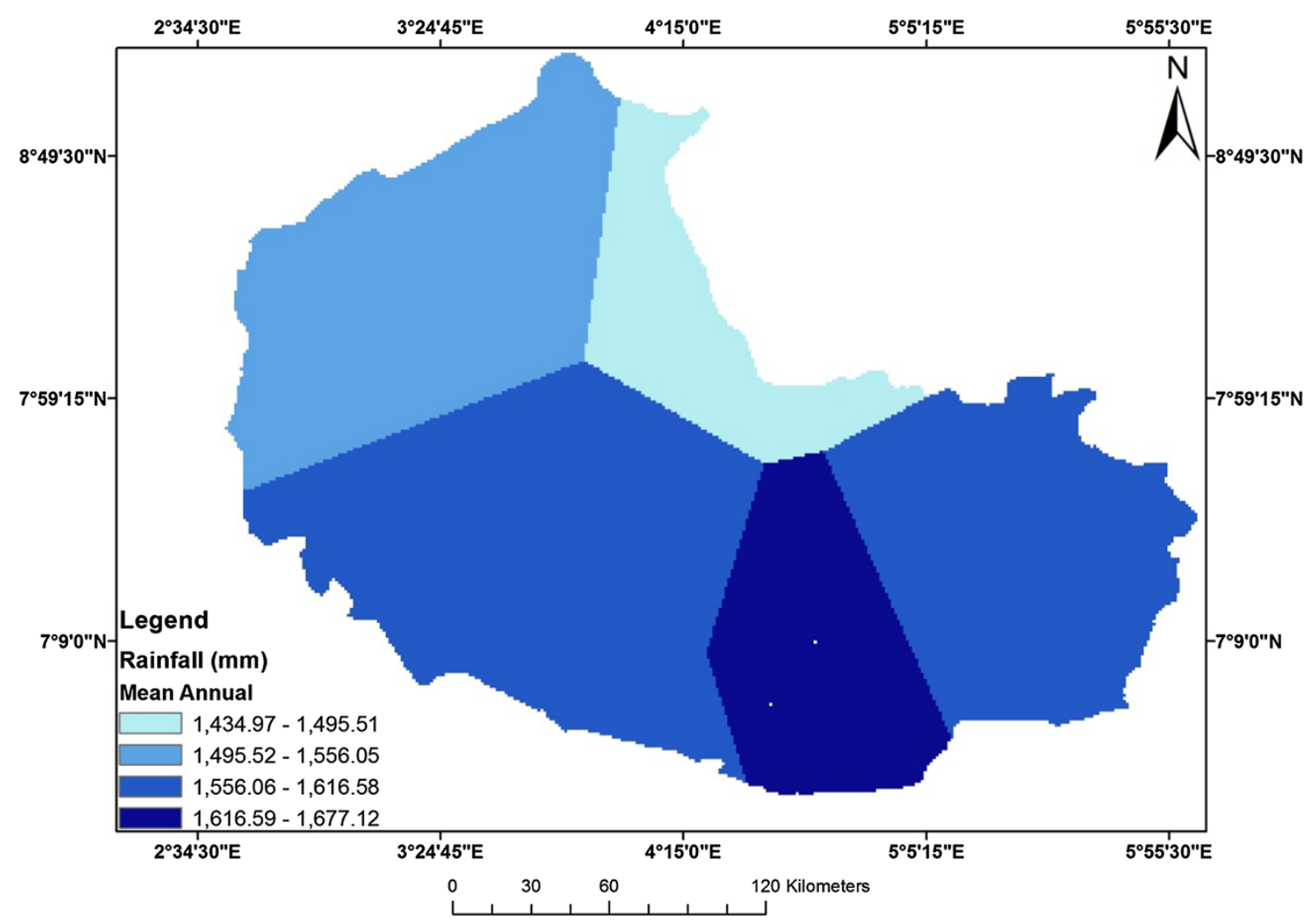

Fig. 9 Rainfall map of the study area 


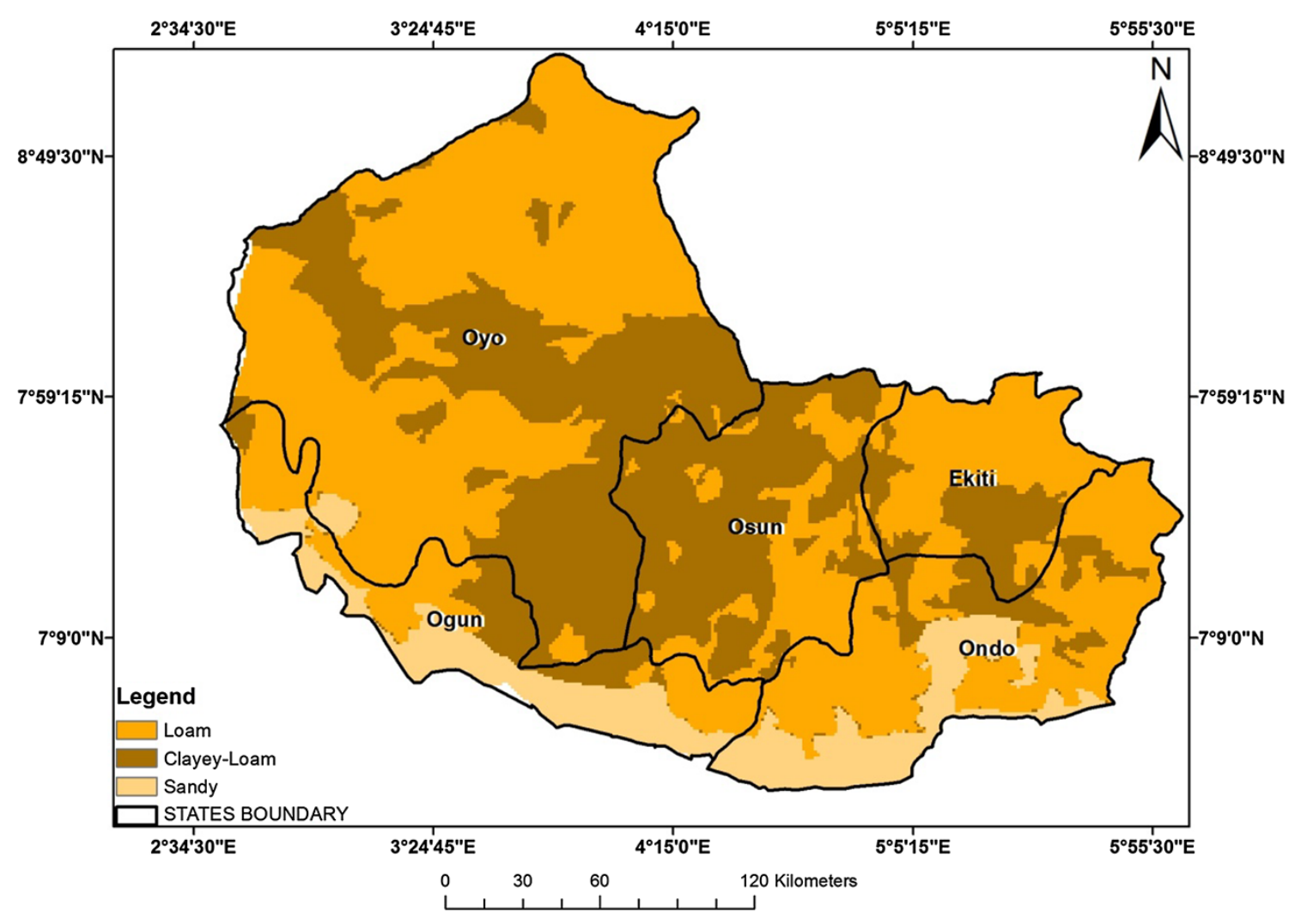

Fig. 10 Soil zones map of the study area

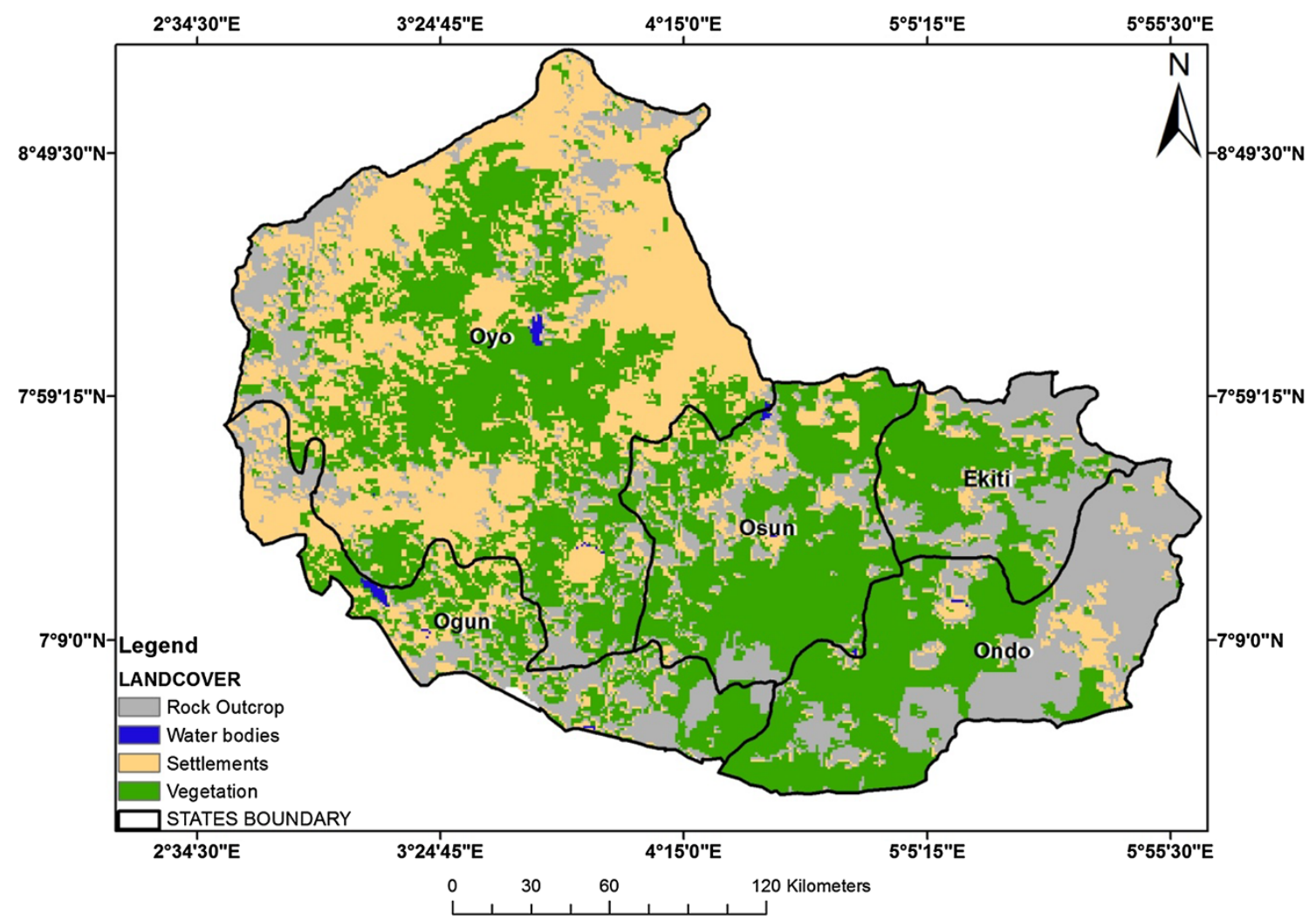

Fig. 11 Landuse/landcover map of the study area 
(69 \%), respectively. This suggest that zones closer to water bodies $(<75 \mathrm{~m})$ are very small in area extent, reflecting low to moderate drainage density and such zones are considered the suitable zone for groundwater availability with a weight value of 0.499 , higher than those areas further away from the water bodies. Nonetheless, a low ranking of 0.022 was assigned to water body proximity theme, due to the limited surface-groundwater interactions in a typical basement setting and thus limited influence on the overall groundwater potential.

\section{Classification of groundwater potential zones}

On the basis of the assignment and normalized weighting of the individual features of the thematic layers, a potential groundwater index map was produced (Fig. 13). The potential groundwater zones (PGZ) of the study area revealed three distinct zones, namely low, moderate and high zones whose distribution and extents are $3,416.54 \mathrm{~km}^{2}$ $(3.23 \%), 84,121.75 \mathrm{~km}^{2}(79.53 \%)$ and $18,239.71 \mathrm{~km}^{2}$ $(17.24 \%)$ as presented in Table 5.

The potential map, as presented in Fig. 13, gives a quick assessment of the occurrence of groundwater resources in the study area. The groundwater potential map revealed that the upper north-western and the extreme eastern parts of the study area generally have low to moderate potentials with area coverage of about $83 \%$, while the southern portion generally exhibits high potentials representing about $17 \%$ of the study area. The generally low to moderate groundwater potentiality of the study area as reflected by $83 \%$ coverage is a confirmation of generally limited aquiferous capability of Basement Complex terrain.

Furthermore, a closer assessment of the groundwater potential map revealed that the distribution is more or less a reflection of the rainfall and soil patterns in addition to the geological control. In addition, areas underlain by migmatite and gneiss especially in the northern and eastern sections of the study area which are characterized by relatively lower annual rainfall have low groundwater potential on the one hand. On the other hand, areas underlain by quartzite and quartz-schist, due to presence of lineament and apparently deep weathering exhibit high groundwater potential while areas underlain by granitic rocks have medium potential. Moreover, high slope percentages, inselbergs and predominance of rock outcrops can be attributed to the observed low groundwater potentials at the eastern portion of the study area. However, high drainage density, high rainfall and low slope percentages which can enhance infiltration of water into the groundwater system can be attributed to the observed high groundwater potential exhibited by the southern portions of the study area.

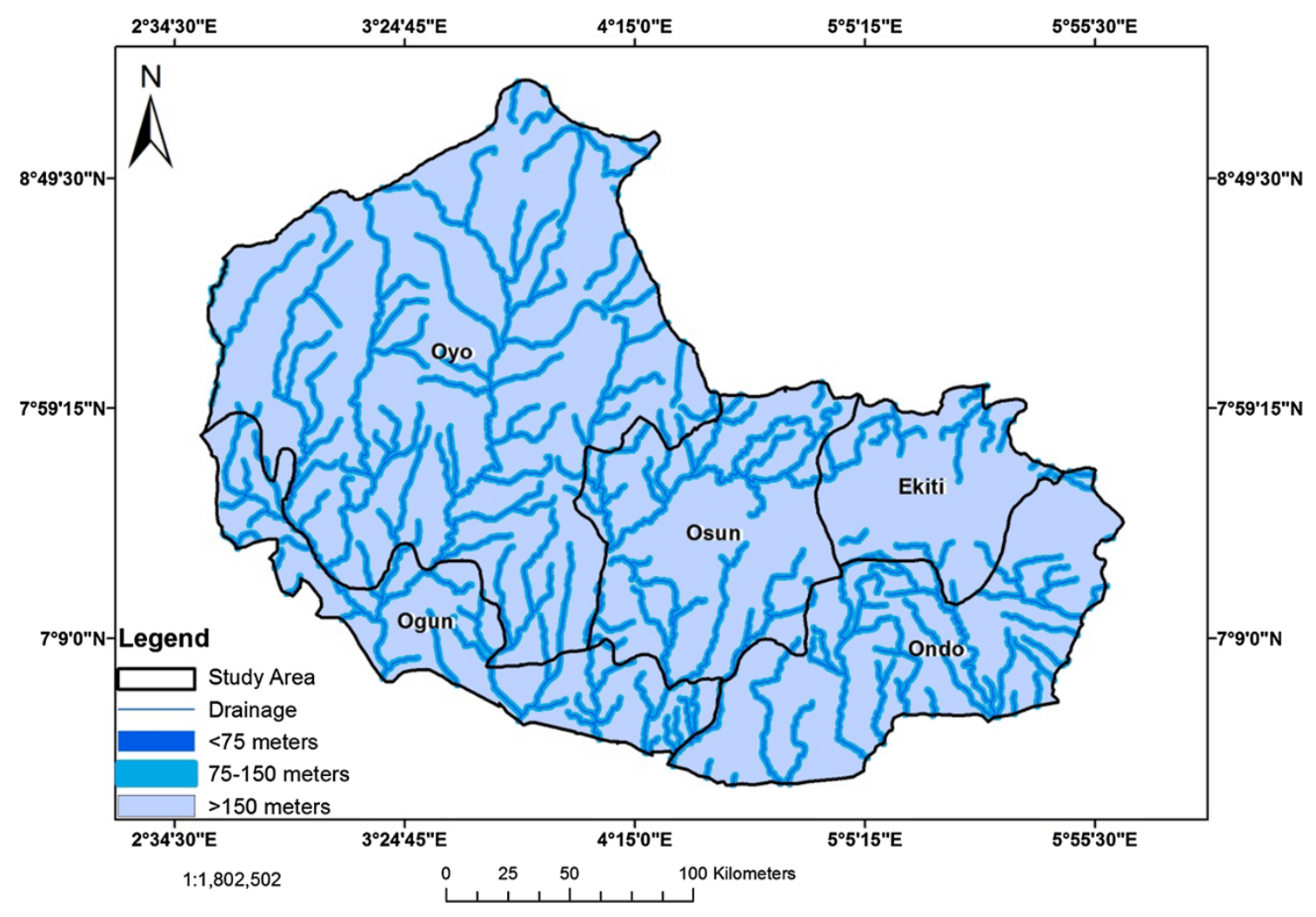

Fig. 12 Water proximity map of the study area 


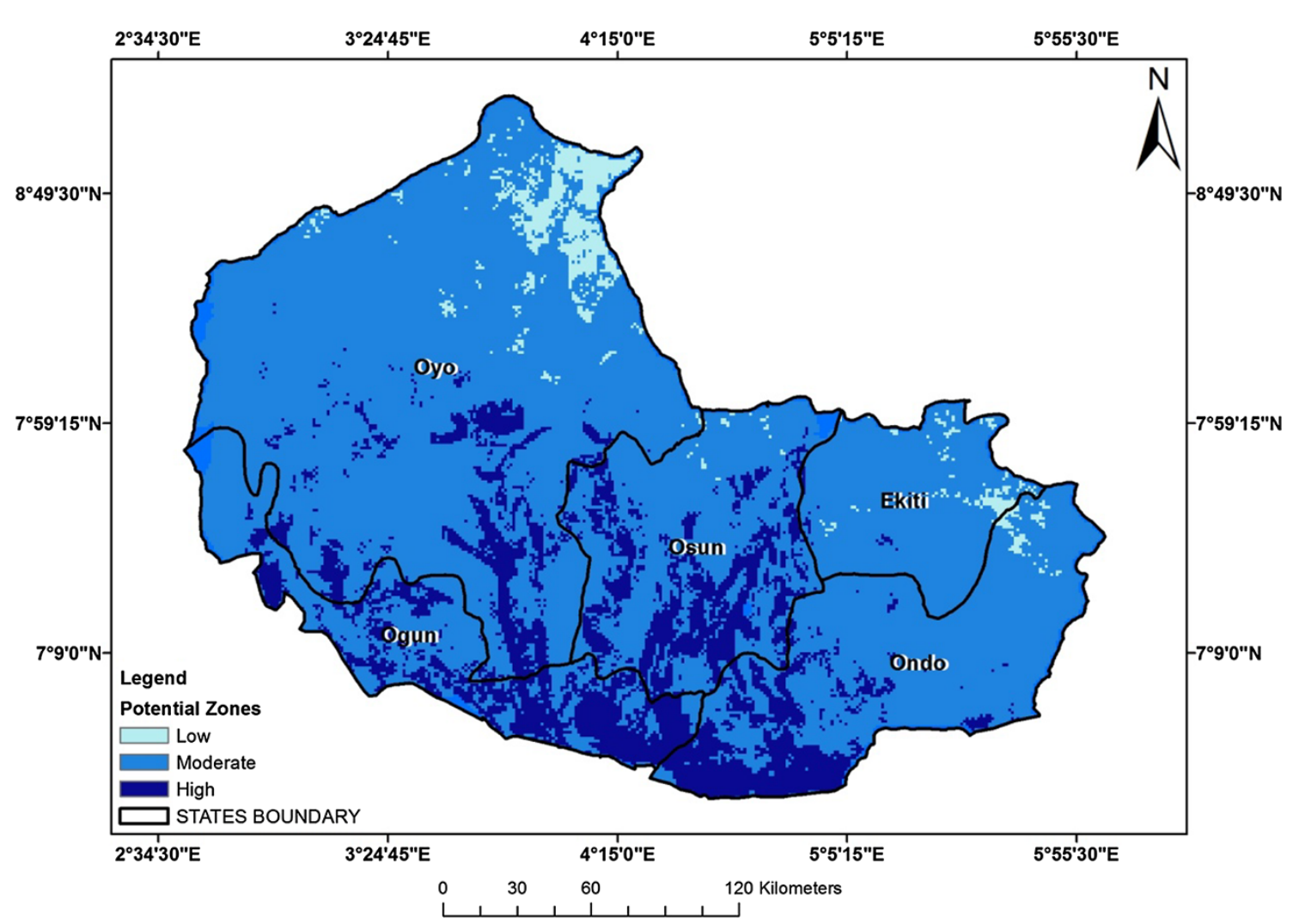

Fig. 13 Potential groundwater zones of the study area

Table 5 Classification of groundwater potential zones and coverage areas alongside the respective yield categories

\begin{tabular}{lrrl}
\hline Potential zones & Area $(\%)$ & Area $\left(\mathrm{km}^{2}\right)$ & Yield classification \\
\hline Low & 3.23 & $3,416.54$ & Low $\left(<75 \mathrm{~m}^{3} /\right.$ day $)$ \\
Moderate & 79.53 & $84,121.75$ & Moderate $\left(75-150 \mathrm{~m}^{3} /\right.$ day $)$ \\
High & 17.24 & $18,239.71$ & High $\left(>150 \mathrm{~m}^{3} /\right.$ day $)$ \\
\hline
\end{tabular}

\section{Validation with borehole yield data}

In order to validate the classification of the groundwater potential zones as revealed by the MCDA, RS and GISbased groundwater potential map, data on existing wells (yield, depth and saturated column) were collated for over 100 boreholes in the study area (Table 6).

Generally, the borehole depth ranges from 22 to $92 \mathrm{~m}$ across the study area which is a reflection varied and erratic nature of the water-bearing zones in a typical basement setting. Also the saturated thickness varies from average of $18.7 \mathrm{~m}$ in migmatite/gneiss to $10.8 \mathrm{~m}$ in granitic rocks and $43.2 \mathrm{~m}$ in quartzite/quartz-schist environment. The yields of the boreholes vary from 30 to $305 \mathrm{~m}^{3} /$ day (av. $94.6 \mathrm{~m}^{3} /$ day) in the quartzite/quartz-schist settings, while varying from 26 to $203 \mathrm{~m}^{3} /$ day (av. $89.4 \mathrm{~m}^{3} /$ day) in Granitic rock settings compared with 22 to $120 \mathrm{~m}^{3} /$ day (av. $67.1 \mathrm{~m}^{3} /$ day) in migmatite and gneiss terrains. The borehole data were superimposed on the groundwater potential map and numbers of wells with different yield ranges for different groundwater potential zones were evaluated. The frequency distribution of various yields in different zones is presented in Fig. 14.

As shown in the diagram, the occurrence of number of wells with yield of $<75 \mathrm{~m}^{3} /$ day (low yield) and in the range of $75-150 \mathrm{~m}^{3} /$ day (moderate yield) cut across the different rock units. However, the high frequency of wells within the migmatite/gneiss settings in the low and moderate yield categories signifies the generally low potentials of these rocks as highlighted by the GIS-based potential map. In addition, the high-yield category ( $\left.>150 \mathrm{~m}^{3} / \mathrm{day}\right)$ is associated with wells in granitic rocks and quartz-schist/quartzite settings. This is also consistent with the moderate and high groundwater potential classification of the GIS map for both rock units.

However, it should be noted that the frequency of the wells decreases from the low- to high-yield categories, a situation that can also be attributed to the generally low to moderate groundwater potential of typical basement terrain like the study area. Finally, favourable zones for highyielding wells mostly within quartzites and quartz-schist settings coincided with area of high and moderately high groundwater potential zones (see Table 4). Also areas of 
Table 6 Summary of existing borehole data for the different bedrock settings

\begin{tabular}{|c|c|c|c|c|c|c|c|c|c|}
\hline \multirow{2}{*}{$\begin{array}{l}\text { Rock units } \\
\text { Parameters }\end{array}$} & \multicolumn{3}{|c|}{ Migmatite/gneiss $(N=59)$} & \multicolumn{3}{|c|}{ Granitic rocks $(N=30)$} & \multicolumn{3}{|c|}{ Quartzite/quartz-schist $(N=22)$} \\
\hline & BH depth & Sat. thick & Yield $\left(\mathrm{m}^{3} /\right.$ day $)$ & BH depth & Sat. thick & Yield $\left(\mathrm{m}^{3} /\right.$ day $)$ & BH depth & Sat. thick & Yield $\left(\mathrm{m}^{3} /\right.$ day $)$ \\
\hline Minimum & 22.8 & 5.70 & 21.6 & 27.9 & 6.0 & 25.9 & 36.0 & 20.9 & 30.0 \\
\hline Maximum & 80.0 & 62.8 & 120.1 & 92.0 & 34.5 & 203.0 & 87.0 & 81.6 & 305.0 \\
\hline Mean & 43.9 & 18.7 & 67.1 & 51.3 & 10.8 & 89.4 & 54.9 & 45.4 & 94.6 \\
\hline Median & 43.0 & 12.5 & 67.9 & 43.4 & 7.2 & 86.4 & 50.0 & 39.2 & 82.8 \\
\hline Std. Dev & 15.1 & 12.6 & 24.8 & 19.9 & 6.8 & 42.8 & 12.7 & 13.7 & 55.8 \\
\hline
\end{tabular}

$B H$ borehole depth in metres, Sat. thick saturated thickness in meters

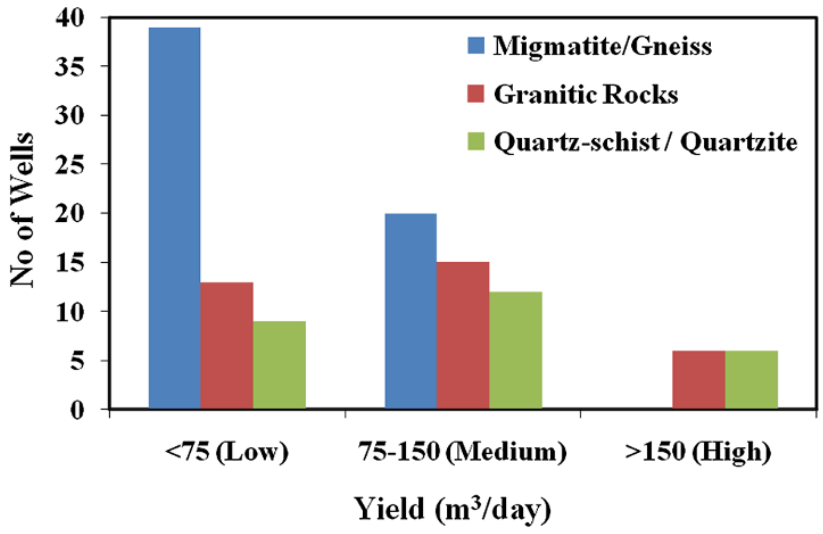

Fig. 14 Groundwater yields in geology types of the study area

low- and moderate-yielding boreholes, characteristic of granite and migmatite/gneiss, coincide with moderate and low groundwater potential zones of the GIS map.

\section{Summary and conclusion}

In this study, MCDA, RS and GIS approaches have been used to integrate various geological and hydrogeomorphological thematic maps, which play major role in occurrence and movement of groundwater. The integrated groundwater potential map has been categorized on the basis of normalized cumulative weightage assigned to different features of thematic maps.

As the GPI is the total weightage of all the factors in an area and the classification of groundwater potential zones represents the relative availability of groundwater, the greater the weight-score, the higher the groundwater potential. The overall integration of the thematic layers revealed that the study area can be categorized into three different groundwater potential zones: high, medium and low. The medium groundwater potential zones occupy about $84,121.8 \mathrm{~km}^{2}$ representing about $78 \%$ of the total area while high groundwater potential zones constitute about $17 \%\left(18,239.7 \mathrm{~km}^{2}\right)$ of the total area. The overall potential map suggests the dominant influence of geology and geomorphological features in the delineation of the groundwater zone; the areas underlain by medium-porphyritic granite, biotite-hornblende granite and granite gneiss bedrock settings has medium groundwater potentials compared to high potentials in the areas characterized by weathered/fractured quartzite, quartz-schist, amphibolite schist and phyllite bedrock settings. Areas of low groundwater potentials constitute only $3 \%\left(3,416.54 \mathrm{~km}^{2}\right)$ of the total study area and are mostly underlain by migmatite, banded and augen gneiss bedrock settings.

Subsequent validation with boreholes/well yield data revealed a good correlation with respect to the observed groundwater potential zonation. Wells/boreholes with yields greater than $>150 \mathrm{~m}^{3} /$ day are generally characteristic of areas with high groundwater potential while those with yields of $75-150$ and $<75 \mathrm{~m}^{3} /$ day are typical of areas with medium and low groundwater potentials, respectively. The validation clearly highlights the efficacy of the integrated MCDA, RS and GIS methods employed in this study as useful modern approach for proper groundwater resource evaluation and sustainable groundwater development. Nonetheless, the groundwater potential zonation presented here can be applied only for regional studies for the purpose of groundwater development, providing quick prospective guides for groundwater exploration and exploitation in such crystalline basement settings, while individual site selection for groundwater development should take into consideration other site-specific conventional ground-truthing methods.

Open Access This article is distributed under the terms of the Creative Commons Attribution License which permits any use, distribution, and reproduction in any medium, provided the original author(s) and the source are credited.

\section{References}

Acworth RI (1987) The development of crystalline basement aquifers in a tropical environment. Q J Eng Geol 20:265-272

Aggarwal R, Kaur S, Juyal D (2009) Micro level assessment of water resources in bist doab tract of Indian Punjab. J Agric Eng 46(2):33-39 
Aigbedion I (2006) Potential for rock polishing enterprises in southwestern Nigeria. Int J Phys Sci 1(1):1-4

Allichi AU (2007) Impacts of bedrock types on hydraulic characteristics of basement Aquifers; A case study of parts of Ibadan Southwest. Unpublished Msc Thesis of the Department of Geology, University of Ibadan, Nigeria

Boutt DF, David WH, Bryan CP, David TL (2001) Identifying potential land use-derived solute sources to stream baseflow using ground water models and GIS. Ground Water 39:24-34

Burrough PA (1986) Principals of geographical information systems for land resources assessment. Clarendon Press, Oxford

Chawla JK, Khepar SD, Sondhi SK, Yadav AK (2010) Assessment of long-term groundwater behaviour in Punjab, India. Water Int 35(1):63-77

Chenini I, Mammou AB, May ME (2010) Groundwater recharge zone mapping using GIS-based multi-criteria analysis: a case study in Central Tunisia (Maknassy Basin). Water Resour Manage 24(5):921-939

Chilton PJ, Foster SD (1995) Hydrogeological characterisation and water-supply potential of basement aquifers in tropical Africa. Hydrogeol J 3(1):36-49

Chowdhury A, Jha MK, Chowdhury VM, Mal BC (2009) Integrated remote sensing and GIS-based approach for assessing groundwater potential in West Medinipur district, West Bengal, India. Int J Remote Sens 30:231-250

Edet AE, Okereke CS (1997) Assessment of hydrological conditions in basement aquifers of the Precambrian Oban massif, southeastern Nigeria. J Appl Geophys 36(4):195-204

Edet AE, Okereke CS, Teme SC, Esu EO (1997) Application of remote sensing data to groundwater exploration: a case study of the cross-river state, southeastern Nigeria. Hydrogeol J 6:394-404

El-kadi AI, Oloufa AA, Eltahan AA, Malic HU (1994) Use of a geographic information system in site-specific groundwater modeling. Ground Water 32:617-625

Elueze AA (1982) Rift system for proterozoic schists belts in Nigeria. Tectonophy 209:167-169

Elueze AA (1995) Prospects for sourcing stone polishing ventures from rock in the Basement Complex of Nigeria. J Min Geosci Soc 31(1):73-77

Forman EH (1983) The analytic hierarchy process as a decision support system. In: Proceedings of the IEEE Computer Society

Forman EH (1990) Random indices for incomplete pairwise comparison matrices. Eur J Oper Res 48(1990):153-155

Gumma MK, Pavelic P (2013) Mapping of groundwater potential zones across Ghana using remote sensing, geographic information systems, and spatial modelling. Environ Monit Assess 185(4):3561-3579

Heywood I, Cornelius S, Carver S (1998) An introduction to geographical information systems. Prentice Hall, New Jersey

Iloeje NP (1981) A new geography of Nigeria, new revised edition. Longman Publishers, London

Jaiswal RK, Mukherjee S, Krishnamurthy J, Saxena R (2003) Role of remote sensing and GIS techniques for generation of groundwater prospect zones towards rural development-an approach. Int J Remote Sens 24:993-1008

Jenson SK, Trautwein CM (1987) Methods and applications in surface depression analysis. In: Proceedings of Auto-Carto 8, Baltimore, pp 137-144

Jha KM, Chowdary VM and Chowdhury A (2010) Groundwater assessment in Salboni Block, West Bengal (India) using remote sensing, geographical information system and multi-criteria decision analysis techniques

Jones MJ (1985) The weathered zone aquifers of the basement complex areas of Africa. Q J Eng Geol 18:35-46
Jones HA, Hockey RD (1964) The geology of part of south-western Nigeria. Geol Surv Nigeria Bull No 31

Khan MA, Maharana PC (2002) Use of remote sensing and GIS in the delineation and characterization of groundwater prospect zones

Krishnamurthy JN, Venkatesa K, Jayaraman V, Manivel M (1996) An approach to demarcate ground water potential zones through remote sensing and geographical information system. Int J Remote Sens 17:1867-1884

Lillesand TM, Kiefer RW (1994) Remote sensing and image interpretation, 3rd edn. Wiley, New York $750 \mathrm{pp}$

MacDonald AM, Davies J, Calow R, Chilton J (2005) Developing groundwater: a guide to rural water supply. ITDG Publishing, Rugby

Machiwal D, Jha MK, Mal BC (2011) Assessment of groundwater potential in a semi-arid region of India using remote sensing, GIS and MCDM techniques. Water Resour Manage 25:1359-1386

McNeill JD (1991) Advances in electromagnetic methods for groundwater studies. Geoexploration 27:65-80

Meijerink AMJ (1996) Remote sensing applications to hydrology: groundwater. Hydrol Sci J 41(4):549-561

Meijerink AMJ (2007) Remote sensing applications to groundwater. IHP-VI, Series on Groundwater No.16. United Nations Educational, Scientific and Cultural Organization

Mukherjee P, Singh CK, Mukherjee S (2012) Delineation of groundwater potential zones in arid region of India- a remote sensing and GIS Approach. Water Resour Manage 26(9):2643-2672

Murthy KSR (2000) Groundwater potential in a semi-arid region of Andhra Pradesh: a geographical information system approach. Int J Remote Sens 21(9):1867-1884

Novaline J, Saibaba J, Prasada R (1999) Groundwater modeling for sustainable development using GIS techniques. Preconference volume 264-267 Geoinformetis Beyond 2000, Dehradun

Obaje, NG (2009) Geology and mineral resources of Nigeria. Lecture Notes in Earth Sciences, vol 120. Springer, Berlin, ISBN 978-3540-92684-9. doi:10.1007/978-3-540-92685-6

Obi Reddy GP, Chandra Mouli K, Srivastav SK, Srinivas CV, Maji AK (2000) Evaluation of groundwater potential zones using remote sensing data- a case study of Gaimukh watershed, Bhandara district, Maharashtra. J Indian Soc Remote Sens 28(1):19-32

Odeyemi IB (1976) Preliminary report of the field relationship of the basement complex rocks around Igarra, Midwest in Kogbe, C.A (1976.ed). Geology of Nigeria, pp 59-63

Oyawoye MO (1970) The basement complex of Nigeria. In: Dessauragie TFJ, Whiteman AJ (eds) African geology. Ibadan University Press, Ibadan, pp 67-78

Oyawoye MO (1972). The Basement complex of Nigeria. African geology, I. Ibadan University Press, Ibadan, pp 67-99

Oyenuga VA (1967) Agriculture in Nigeria. Food and Agriculture Organization (FAO), Rome

Prasad RK, Mondal NC, Banerjee P, Nandakumar MV, Singh VS (2008) Deciphering potential groundwater zone in hard rock through the application of GIS. Environ Geol 55:467-475

Pratap K, Ravindran KV, Prabakaran B (2000) Groundwater prospect zoning using remote sensing and Geographical Information System: a case study in Dala-Renukoot Area, Sonbhadra District Uttar Pradesh. J Indian Soc Remote Sens 28(4):249-263

Rahaman MA (1976) Review of the basement geology of south western Nigeria. In: Kogbe CA (ed) Geology of Nigeria. Elizabehan Publishers, Lagos, pp 41-58

Rao NS (2006) Groundwater potential index in a crystalline terrain using remote sensing data. Environ Geol 50:1067-1076

Rao YS, Jugran DK (2003) Delineation of groundwater potential zones and zones of groundwater quality suitable for domestic 
purposes using remote sensing and GIS. Hydrol Sci J 48(5):821-833

Rodell M, Velicogna I, Famiglietti JS (2009) Satellite-based estimates of groundwater depletion in India. Nature 460:999-1002

Rokade VM, Kundal P, Joshi AK (2007) Groundwater potential modeling through remote sensing and GIS: a case study from Rajura Taluka, Chandrapur District, Maharashtra. J Geol Soc India 69:943-948

Saaty TL (1980) The analytic hierarchy process: planning, priority setting, resource allocation. McGraw-Hill, New York

Saaty TL (1992) Decision making for leaders. RWS Publications, Pittsburgh

Sander P, Chesley MM, Minor TB (1996) Groundwater assessment using remote sensing and GIS in a rural groundwater project in Ghana: lessons learned. Hydrogeol J 4(3):40-49

Saraf AK, Choudhary PR (1998) Integrated remote sensing and GIS for ground water exploration and identification of artificial recharge site. Int J Remote Sens 19:1825-1841

Saraf AK, Choudhury PR, Roy B, Sarma B, Vijay S, Choudhury S (2004) GIS based surface hydrological modelling in identification of groundwater recharge zones. Int $\mathrm{J}$ Remote Sens 25(24):5759-5770

Satty TL (1986) Axiomatic foundation of the analytic hierarchy process. Manage Sci 32(7):841-855

Shahid S, Nath SK, Roy J (2000) Ground water potential modeling in soft rock area using GIS. J Remote Sens 21:1919-1924

Singh AK, Prakash SR (2002) An integrated approach of remote sensing, geophysics and GIS to evaluation of groundwater potentiality of Ojhala sub watershed, Mirzapur District, U.P. India (http://www.GISdevelopment.net)

Singh AK, Panda SN, Kumar KS (2013) Artificial groundwater recharge zones mapping using remote sensing and GIS: a case study in Indian Punjab. Environ Earth Sci 62(4):871-881

Sreedevi PD, Srinivasulu S, Raju KK (2001) Hydrogeomorphological and groundwater prospects of the Pageru river basin by using remote sensing data. Environ Geol 40:1919-1924

Srivastava PK, Bhattacharya AK (2006) Groundwater assessment through an integrated approach using remote sensing, GIS and resistivity techniques: a case study from a hard rock terrain. Int J Remote Sens 27(20):4599-4620

Taylor R, Howard K (2000) A tectono-geomorphic model of the hydrogeology of deeply weathered crystalline rock: evidence from Uganda. Hydrogeol J 8(3):279-294

Teeuw RM (1995) Groundwater exploration using remote sensing and a low-cost geographical information system. Hydrogeol J 3:21-30

Tijani MN (1994) Hydrochemical assessment of groundwater in Moro area, Kwara State, Nigeria. Environ Geol 24(3):194-202

Talabi AO, Tijani, MN (2011) Integrated remote sensing and GIS approach to Ground-water potential assessment in the basement terrain of Ekiti area south-western Nigeria. RMZ - materials and geoenvironment, vol 58, no 3, pp 303-328

Wright EP, Burgess WG (1992) The hydrogeology of crystalline basement aquifers in Africa. Geol Soc Spec Publ No 66:1-27 